\title{
A diverse group of professionals need skills to spot risk under the FCPA and related laws
}

Spotting risk under the FCPA and related laws is a fundamental skill set for a diverse group of professionals because business organizations face omnipresent risk when competing in the global marketplace. While all seem to acknowledge this, in the minds of some, complying with such laws should be easy: "just don't bribe." Unfortunately, a few companies engaged in international business do so with an intent to bribe as a business strategy and without a commitment to compliance. However, this chapter demonstrates that the simplistic narrative of "just don't bribe" is a fallacy because the overwhelming majority of business organizations subject to the FCPA and related laws are engaged in business with a commitment to compliance, yet subject to unrealistic legal standards and/or difficult and complex business conditions that often serve as the root cause of scrutiny and enforcement. An examination of these root causes is not meant to excuse the conduct giving rise to an enforcement action, but rather to understand how and why the conduct occurred in the first place. Understanding the root causes of scrutiny and enforcement also serves an important compliance objective in that a key component of best practices is conducting a risk assessment (i.e. understanding unique points of contact with "foreign officials") and prioritizing compliance to specific risks.

This chapter next highlights that a diverse group of professionals also need skills to spot risk because scrutiny and enforcement have wideranging negative financial consequences for business organizations. Obviously one reason to comply with the FCPA and related laws is because non-compliance can expose an organization to an actual enforcement action brought by law enforcement. However, settlement amounts in an actual enforcement action are often only a relatively minor component of the overall financial consequences that can result from scrutiny 
and enforcement. Discussion of these many other "ripples" is intended to shift the compliance conversation away from a purely legal issue to its more proper designation as a general business issue that needs to be on the radar screen of various professionals who can assist in risk management and who should view the importance of compliance holistically and not merely through the narrow lens of actual enforcement actions.

\section{Omnipresent risk}

The FCPA and related laws are most logically implicated when engaged in international business and business organizations (large and small and across a variety of industry sectors) are doing just that to achieve business goals. According to a recent analysis, many U.S. companies conduct nearly as much business overseas as they do in the U.S. ${ }^{1}$ and financial information from companies across a variety of industry sectors highlights the prominence of international business. For instance, consumer products company Procter \& Gamble derives approximately $60 \%$ of its sales from outside of North America, its products are sold in approximately 180 countries and it has facilities in approximately 40 countries. Likewise, footwear and apparel company Nike derives approximately $60 \%$ of its revenue from outside the U.S. and has approximately 400 stores outside the U.S. as well as 16 distribution centers. For many companies, doing business in high-risk bribery jurisdictions such as China, India and Brazil is necessary to sustain growth and satisfy shareholder demand for profits. As the CEO of a large multinational company rhetorically asked, "Where do you think the growth in the world is going to come from? Would you bet on the U.S.? Would you bet on Western Europe? It's going to come from emerging markets." ${ }^{2}$

More business in international markets means more engagement of foreign third parties, more points of contact with alleged "foreign officials," and more exposure to difficult and challenging business requirements and trade barriers that often create the conditions in which bribery can flourish. Against this backdrop, it is not surprising that there has generally been more enforcement of the FCPA and related laws during the past decade for the same reason that more cars on the road result in more accidents, traffic violations and speeding tickets.

In short, the FCPA is a top legal and compliance concern for business organizations (both public and private and across a variety of industry 
Table 1.1 Representative enforcement actions

\begin{tabular}{ll}
\hline Business organization & Industry \\
\hline Allianz & Insurance \\
Avon & Beauty products \\
BHP Billiton & Mining \\
Biomet & Medical devices \\
Bristol Myers Squibb & Pharmaceutical \\
Embraer & Air transportation \\
Goodyear & Tires \\
Halliburton & Oil and gas \\
JPMorgan & Financial services \\
Las Vegas Sands & Hotel and gaming \\
Mondelez International & Food products \\
Oracle & Software \\
Qualcomm & Technology \\
Ralph Lauren & Apparel \\
SQM & Chemical \\
VimpelCom & Telecommunications \\
\hline
\end{tabular}

sectors) doing business in the global marketplace. Reflective of the omnipresent nature of scrutiny and enforcement, Table 1.1 highlights the variety of business organizations that have recently resolved enforcement actions.

While many of the business organizations represented in Table 1.1 are large, publicly traded companies, smaller companies, privately held companies, and other forms of business organization such as limited liability companies (collectively referred to as small-to-medium-size enterprises - SMEs) have also recently resolved enforcement actions as highlighted in Table 1.2.

Indeed, in connection with an enforcement action against Smith \& Wesson the SEC stated:

This is a wake-up call for small and medium-size businesses that want to enter into high-risk markets and expand their international sales. When a company makes the strategic decision to sell its products overseas, it must ensure that the right internal controls are in place and operating. ${ }^{3}$

The omnipresent nature of scrutiny and enforcement is not just reflected by the variety of business organizations in a variety of 
Table 1.2 SMEs that have recently resolved FCPA enforcement actions

$\begin{array}{llll}\text { Louis Berger } & \text { IAP Worldwide } & \text { FLIR Systems } & \text { PBSJ Corp. } \\ \text { Dallas Airmotive } & \text { Bruker Corp. } & \text { Layne Christensen } & \text { Smith \& Wesson } \\ \text { Bio-Rad } & \text { NORDAM Group } & \text { Data Systems } & \text { BizJet International } \\ \text { Watts Water Tech. } & \text { Comverse Tech. } & \text { Maxwell Tech. } & \text { Akamai Tech. } \\ \text { Analogic } & \text { CDM Smith } & \text { Alliance One } & \text { Armor Holdings } \\ \text { Lindsey Manuf. } & \text { RAE Systems } & \text { Veraz Networks } & \text { NATCO Group } \\ \text { Cinergy Telecom } & \text { Latin Node } & \text { UTStarcom } & \text { Helmerich \& Payne } \\ \text { Nature's Sunshine } & \text { Control Components } & \text { Nexus Tech. } & \text { AGA Medical } \\ \text { Delta \& Pine Land } & \text { Nortek } & \text { Nu Skin Enterprises } & \text { NCH Corp. }\end{array}$

industry sectors that have resolved enforcement actions, but also by the below map which pinpoints the locations generating corporate FCPA enforcement actions in just one recent year.

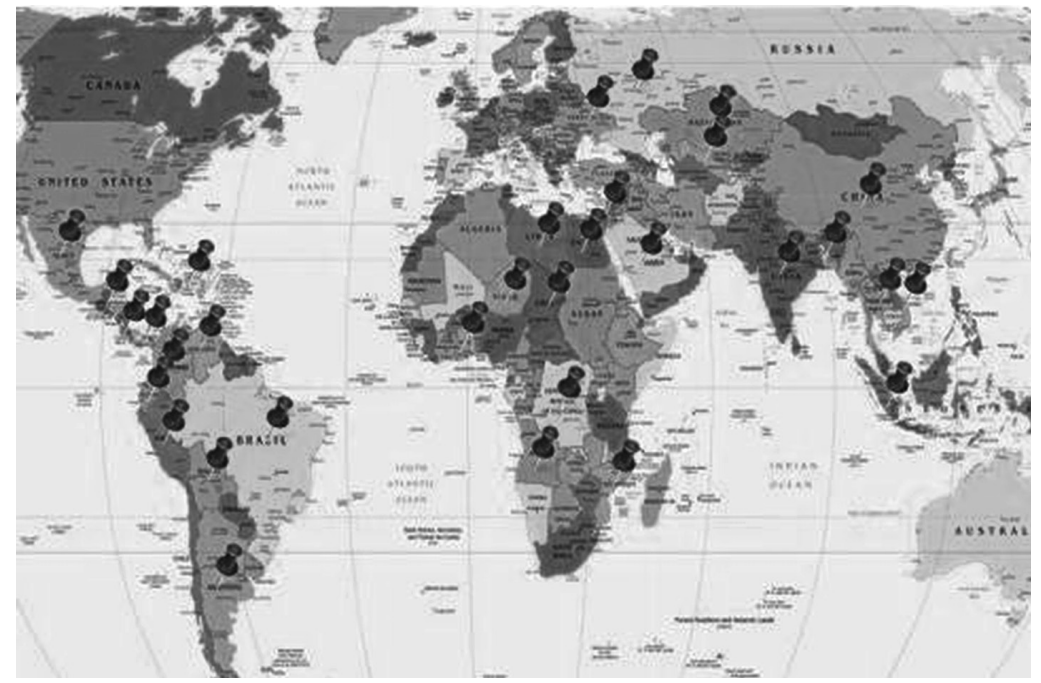

While certain countries may have a higher risk profile than others, enforcement actions have involved conduct in approximately 80 countries, including perceived low-risk countries such as Canada, the U.K., the Netherlands, France, and Germany. All seem to acknowledge that risk under the FCPA and related laws is omnipresent when doing 
business in the global marketplace. However, in the minds of some, compliance should be easy: "just don't bribe." However, as next discussed, this simplistic narrative is a fallacy.

\section{The fallacy of "just don't bribe"}

In the minds of some, you wasted your money purchasing a book titled Strategies for Minimizing Risk Under the Foreign Corrupt Practices Act and Related Laws, because compliance should be easy: "just don't bribe." "Good Companies Don't Bribe. Period" was actually the title of a business column in a major U.S. newspaper which assailed those who have criticized various aspects of FCPA enforcement. In support of the position that "good companies don't bribe - period," the column stated:

The [FCPA] has established America's reputation as a strong proponent of ethical business practices abroad. As Microsoft recognizes in its anti-corruption policy: 'corruption promotes poverty, hunger, disease and crime, and keeps societies and individuals from reaching their full potential. Corruption is one of the leading obstacles to economic and social development. Microsoft is committed to observing the standards of conduct set forth in the [FCPA] and the anti-corruption and anti-money-laundering laws of the countries in which it operates.' ${ }^{4}$

The absolutist position that "good companies don't bribe - period" was undermined a few months later when it was reported that both the DOJ and SEC "opened preliminary investigations into bribery accusations involving Microsoft in China, Italy and Romania." ${ }^{5}$ A Microsoft executive acknowledged the investigation and stated:

Like other large companies with operations around the world, we sometimes receive allegations about potential misconduct by employees or business partners, and we investigate them fully regardless of the source. We also invest heavily in proactive training, monitoring and audits to ensure our business operations around the world meet the highest legal and ethical standards. [...] We are a global company with operations in 112 countries, nearly 98,000 employees and 640,000 business partners. [...] We have more than 50 people whose primary role is investigating potential breaches of company policy, and an additional 120 people whose primary role is compliance. In addition, we sometimes retain outside law firms to conduct or assist with investigations. This is a reflection of the size 
and complexity of our business and the seriousness with which we take meeting our obligations. We also invest in proactive measures including annual training programs for every employee, regular internal audits and multiple levels of approval for contracting and expenditure. In a company of our size, allegations of this nature will be made from time to time. It is also possible there will sometimes be individual employees or business partners who violate our policies and break the law. In a community of 98 ,ooo people and 640,000 partners, it isn't possible to say there will never be wrongdoing. ${ }^{6}$

The Microsoft example highlights that scrutiny and enforcement can be viewed in the following ways. Do companies subject to the FCPA do business in foreign markets:

- intent on engaging in bribery as a business strategy and without a commitment to compliance; or

- with a commitment to compliance, yet subject to unrealistic legal standards and/or difficult and complex business conditions?

Regrettably, there have been and will continue to be instances of the former. For instance, in the Siemens enforcement action the government stated that:

- "for much of its operations across the globe, bribery was nothing less than standard operating procedure for Siemens";

- the "pattern of bribery by Siemens was unprecedented in scale and geographic reach";

- Siemens had a "corporate culture in which bribery was tolerated and even rewarded at the highest levels of the company"; and

- "compliance, legal, internal audit, and corporate finance departments" of the company played a significant role in the conduct at issue. $^{7}$

On a much smaller yet still egregious scale, an enforcement action against BizJet International (a small, privately held company) involved conduct by various executives at the highest levels of the 
company as well as the Board of Directors being specifically informed by certain executives that the company "would pay referral fees in order to gain market share" in various foreign countries. ${ }^{8}$ In Siemens, BizJet and a few other enforcement actions the otherwise naïve and simplistic phrase "just don't bribe" accurately summarizes the conduct at issue.

However, not all companies that are under scrutiny and resolve enforcement actions deserve the "bad" or "unethical" label. Joseph Covington, a former DOJ FCPA Unit Chief, was spot-on when he observed: "rarely [has he] seen American companies affirmatively offering bribes in the first instance." Rather, he observed that companies doing business in global markets are "reacting to a world not of their making" and that "as the world shrinks companies who seek to do the right thing can't help but confront corrupt officials - as customers, regulator and adjudicators - and confront them often." Indeed, one of the ironies of the FCPA's modern era is that several companies have resolved enforcement actions or have been the subject of scrutiny during the same general time period as being recognized as one of the "World's Most Ethical Companies,"10 "Most Admired Companies,"11 or "Companies That Are Changing the World." 12

What often makes compliance difficult for even the most well-managed and well-intentioned business organization is that the basic question of what the FCPA even captures is seldom straightforward. For instance, various courts have found that the anti-bribery provisions contain ambiguous terms and the books and records and internal controls provisions are qualified through a reasonableness standard and good faith concepts. Thus, many of the FCPA's prohibitions are not rules-based but rather principle-based, making compliance difficult in much the same way traffic compliance would be difficult if the speed limit was "reasonable" and not a specific standard such as 65 miles per hour. Even the DOJ and the SEC acknowledge that difficult questions often arise under the FCPA. For instance, the U.S. Attorneys' Manual states: "The investigation and prosecution of particular allegations of violations of the FCPA will raise complex enforcement problems abroad as well as difficult issues of jurisdiction and statutory construction." ${ }^{13}$ Likewise, as previously highlighted, the SEC's Director of Enforcement has stated that "FCPA law ... is not well developed." 14

Another reason compliance can be difficult for even the most wellmanaged and well-intentioned business organization is because of 
the shifting and often conflicting messages the enforcement agencies deliver to the business community. For instance, the FCPA Guidance (a non-binding policy document issued by the DOJ and SEC setting forth their FCPA enforcement approach and priorities) states:

Devoting a disproportionate amount of time policing modest entertainment and gift-giving instead of focusing on large government bids, questionable payments to third-party consultants, or excessive discounts to resellers and distributors may indicate that a company's compliance program is ineffective. A \$50 million contract with a government agency in a high-risk country warrants greater scrutiny than modest routine gifts and entertainment. Similarly, performing identical due diligence on all third-party agents, irrespective of risk factors, is often counter-productive, diverting attention and resources away from those third parties that pose the most significant risk. ${ }^{15}$

In connection with the FCPA Guidance, the Assistant Attorney General stated that the DOJ is "focused on bribes of consequence - ones that have a fundamentally corrosive effect on the way companies do business abroad." ${ }^{16}$ Likewise, the Chief of the SEC Enforcement Division stated that the enforcement agencies "hope that [the Guidance] will clear up some myths about the type of conduct that gets prosecuted under the FCPA - that it is not the $\$ 5$ cup of coffee, or the one off $\$ 50$ gift to a public official, that companies need to be concerned about, but payments of real and substantial value that clearly represent an unambiguous intent to bribe a foreign official to obtain or retain business." ${ }^{17}$ The SEC official further stated that the government was "interested in companies spending compliance dollars in the most sensible way" and hoped that the Guidance and the hypotheticals provided in it would help companies decide where they can "minimize investment and where they can maximize it." 18 The Assistant Attorney General added that the government wants compliance programs "to address real matters of concern." ${ }^{19}$

Notwithstanding sensible enforcement agency guidance and statements, recent enforcement actions have involved allegations about corporate hospitality, travel and entertainment, charitable donations, internships and hiring practices, and other inconsequential things of value such as perfume, dresses and handbags; a bottle of wine; a watch; a camera, kitchen appliances and business suits; television sets, laptops and appliances; tea sets and office furniture; and golf in the morning and beer drinking in the evening. ${ }^{20}$ Do recognize that such 
inconsequential things of value are often not the only allegations or findings in an enforcement action. However, such non-determinative allegations or findings can be viewed in one of two ways: either the government was practicing its typing skills; or the government was sending a message to the business community of the types of conduct they view as being actionable under the FCPA.

Andrew Weissmann, who would later become Chief of the DOJ's Fraud Section, stated that a company that wants to do business in certain countries like China "is going to trip up on many of the provisions of the FCPA [and] will likely have an FCPA problem and it will make it very easy for the people in the DOJ and SEC to basically impose a tax for doing business in that country." ${ }^{21}$

FCPA practitioners, including a former DOJ FCPA enforcement attorney, have also stated:

The world of business ... frequently operates in territory that is somewhat grey: a world in which business persons strive to grow the company ethically in situations where the application of the existing rules are not entirely clear. For instance, in the current era of FCPA enforcement, international businesses struggle with their responsibilities to monitor and control the conduct of third parties with whom they do business: distributors and subdistributors, joint venture partners, dealers, and resellers. Even for companies that are firmly dedicated to compliance with the FCPA, it is not always clear when a third party amounts to an agent whose improper conduct might someday be ascribed to the company and its employees. Good and ethical companies struggle, every day, with the concept of defining an agent of the company as opposed to an independent customer who engages in an arm's-length transaction to purchase the company's products. ${ }^{22}$

Recognizing that the absolutist "good companies don't bribe - period" narrative is a fallacy is an important starting point for this book and gives you a better understanding for why compliance can be difficult for even the most well-managed and well-intentioned business organizations and why risk can't be eliminated when doing business in the global marketplace. Returning to the Microsoft example, some may ask how Microsoft, a company championed as a leader in ethical and compliant business conduct, became the subject of scrutiny? More sophisticated observers should recognize that it is for the same reasons that many ethically sound business organizations find themselves in 
the same position and that is because of the typical root causes of scrutiny and enforcement next discussed.

\section{Root causes of risk}

This section highlights various real-world dynamics and conditions which often lead to scrutiny and enforcement under the FCPA and related laws, in other words the root causes of risk as demonstrated by the below visual.

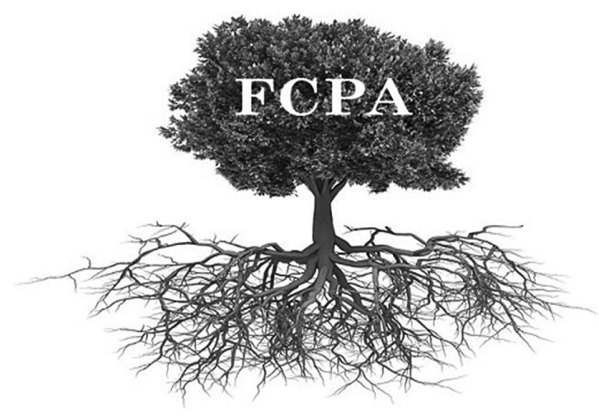

As referenced earlier in this chapter, scrutiny and enforcement can be viewed the following ways: do companies subject to the FCPA do business in foreign markets

- intent on engaging in bribery as a business strategy and without a commitment to compliance; or

- with a commitment to compliance, yet subject to unrealistic legal standards and/or difficult and complex business conditions?

Regrettably, there have been and will continue to be instances of the former similar to the Siemens and BizJet International enforcement actions (often referred to as active bribery). However, the root causes of scrutiny and enforcement are more often the latter (often referred to as passive bribery). An examination of the root causes of scrutiny and enforcement, such as legal principles relevant to business organizations and various realities of the global marketplace, is not meant to excuse the conduct, but rather to understand how and why the conduct occurred in the first place. Moreover, understanding typical root causes of scrutiny and enforcement is an important 
foundational skill relevant to conducting the risk assessment in Chapter 6.

\section{Relevant legal principles}

Risk under the FCPA and related laws arises when a business organization has points of contact with alleged "foreign officials" in the global marketplace. Business organizations are legal persons and thus can only have these points of contact through natural persons such as employees and agents hired or engaged by the organization. These natural persons may develop interests and motivations that do not always align with their employer or principal, not to mention being from different cultures, speaking different languages, and being located in different time zones thousands of miles from corporate headquarters. Even with compliance best practices, the practical reality of monitoring and supervising this vast and diverse network of individuals is difficult and no compliance program can prevent all misconduct.

In the minds of some, rogue actors who circumvent and act inconsistent with pre-existing compliance policies and procedures are a figment of the corporate apologist's imagination. ${ }^{23}$ However, rogue actors actually do exist and no compliance program can ever prevent all wrongdoing by an organization's employees and agents. The DOJ recognizes this as a matter of policy in its U.S. Attorneys' Manual which states that "no compliance program can ever prevent all criminal activity by a corporation's employees." ${ }^{24}$ In addition, high-ranking DOJ officials have recognized that "there will always be employees who decide to take matters into their own hands - they are a fact of life," and that "even the best compliance program may not stop fraud or corruption from occurring." ${ }^{25}$ The former Assistant Chief of the DOJ's FCPA Unit candidly stated "most government attorneys realize that a company can take every reasonable step to prevent wrongdoing but ultimately is powerless if somebody really wants to break the law." 26

Notwithstanding the existence of rogue actors who may circumvent and act inconsistent with pre-existing compliance policies and procedures, business organizations are often subject to scrutiny and enforcement because of the general U.S. legal principle of respondeat superior which states that employee and agent conduct can expose a business organization to legal liability, both criminal and civil, to the extent 
the individual: (i) acted within the scope of their duties; and (ii) the conduct was intended, at least in part, to benefit the organization.

For instance, software company SAP conducts business around the world through 272 subsidiaries, 280,00o individuals, and a network of 11,500 partners. Yet SAP resolved an enforcement action based on the conduct of Vicente Garcia (a former head of Latin America sales) based on government findings that:

- he "created a slush fund" that was used to pay the bribes and kickbacks;

- he "concealed his scheme from others at SAP";

- he "circumvented SAP's internal controls";

- he "justified the excessive discounting by falsifying SAP's internal approval forms";

- he "self-profited through kickbacks";

- he used his "personal e-mail" in connection with the scheme; and

- all of his accomplices were "others outside of SAP" (a term used by the government multiple times). ${ }^{27}$

Likewise, health science company Nordion resolved an enforcement action based on the conduct of Mikhail Gourevitch (a former engineer) who (along with his "childhood friend from Russia" who later became a Nordion agent) "conspired to use a portion of the funds Nordion paid the Agent to bribe Russian government officials to obtain approval for TheraSphere", a liver cancer therapy. According to the government, Gourevitch:

- received kickbacks from the Agent and "secretly enrich[ed] himself" and received "at least $\$ 100,000$ for his role in the arrangement which was not disclosed to Nordion"; and

- "hid the scheme from Nordion" through, among other things, misrepresentations to his employer. ${ }^{28}$

Similarly, thermal imaging company FLIR Systems resolved an enforcement action based on the conduct of two individuals: Stephen 
Timms (Head of FLIR's Middle East Office) and Yasser Ramahi (a business development employee who reported to Timm). According to the government, the individuals "concealed" the extent and nature of the travel and gifts provided to "foreign officials" which gave rise to the enforcement action as well as prepared false and misleading documents in connection with their bribery scheme. The conduct of the two individuals was inconsistent with FLIR's existing FCPA-related policies and internal controls as the government stated:

During the relevant time, FLIR had a code of conduct, as well as a specific anti-bribery policy, which prohibited FLIR employees from violating the FCPA. FLIR's policies required employees to record information "accurately and honestly" in FLIR's books and records, with "no materiality requirement or threshold for a violation." FLIR employees, including Timms and Ramahi, received training on their obligations under the FCPA.

As these enforcement actions demonstrate, respondeat superior is an extremely flexible legal principle that serves as the root cause for many instances of scrutiny and enforcement. In thinking about respondeat superior, recall Microsoft's scrutiny and how the company has operations in 112 countries with nearly 98,00o employees and 640,00o business partners. Against this backdrop, the Microsoft executive was spot-on when observing "in a company of our size, it isn't possible to say there will never be wrongdoing."

Normally $99 \%$ success is rewarded. For instance, if a student scores $99 \%$ on a final exam, she will have the top grade in the class. If a basketball player makes $99 \%$ of his shots, or a soccer player scores a goal on $99 \%$ of her kicks, that player is destined for the hall of fame. In these real-world scenarios, we judge success holistically and not through the narrow lens of one question on an exam or one possession in a sports contest. However, $99 \%$ compliance success in a business organization means $1 \%$ non-compliance and instead of judging an organization's success holistically, government enforcement agencies seem to view an organization through the narrow lens of one employee, one business transaction, or one business unit or subsidiary. Because of respondeat superior, this means legal liability for the business organization and an FCPA practitioner stated:

I think that companies' main frustration is that even with an outstanding compliance program and $99 \%$ of the employees maintaining strict adherence 
to the laws, you can still have violations which expose the entire company to extraordinarily serious penalties. I think the government has, at times, lost track of the main motivations for this statute and has become focused on the amounts of penalties, the imposition of compliance monitors, and exercising government control over what are basically private businesses. The vast majority of companies are absolutely committed to following the spirit and the letter of the FCPA, but when a company gets into trouble, the whole enterprise can be put at risk because of the conduct of a few people, and that doesn't seem right. ${ }^{29}$

As highlighted in this book's introduction, the legal principle of respondeat superior is controversial and materially different compared with corporate liability principles in other peer countries. While the DOJ and SEC have stated that they may consider the unique facts and circumstances relevant to the extent of wrongdoing as well as an organization's pre-existing compliance policies and procedures when determining how to resolve an action or how to calculate a settlement amount, the fact remains that a business organization's pre-existing good faith compliance efforts are not relevant as a matter of law to legal liability under the FCPA. This policy issue aside, the point here is that respondeat superior is often a root cause of scrutiny and enforcement for many business organizations.

Another common root cause of scrutiny and enforcement related to respondeat superior is the reality of parent-subsidiary relationships and expansive enforcement theories related to corporate hierarchies. For instance, many multinational companies are organized for practical and legal reasons through distinct corporate entities such as a parent corporation and various subsidiary companies in foreign countries. It is black-letter law that the legal liability of each distinct corporate entity is contained within that entity absent a finding of abuse of corporate form such as insufficient capitalization or failure to abide by certain formalities such as holding annual meetings or maintaining separate books and records. In other words, legal liability does not ordinary hop, skip and jump around a multinational company. However, in certain enforcement actions (particularly those charging or finding books and records and internal controls violations), the enforcement agencies seemingly advance the theory that a parent corporation is legally responsible for the acts of subsidiary employees even though there is no allegation or suggestion that the parent company was aware of, or participated in, the alleged improper conduct. 
Commenting on this trend in connection with an enforcement action against Ralph Lauren Corporation ("RLC"), Philip Urofsky (a former DOJ Assistant Chief of the Fraud Section) asked "are there any limits to parent corporation liability" and stated:

The facts of the case ... point to the steady entrenchment of a more ominous prosecution theory: an approach that appears to approximate strict criminal and civil liability of parent corporations for their subsidiaries' corrupt acts. Although this disregard of corporate structures has been hinted at in previous SEC matters [... ] the RLC case puts both agencies firmly in the camp of this aggressive and unprecedented expansion of corporate liability. [.. .] This approach, however, fails to honor the corporate form and the black-letter rule that to 'pierce the corporate veil' the government and other litigants must show that the parent operated the subsidiary as an alter ego, and itself paid no attention to the corporate form. Moreover, it is contrary to the language of the [FCPA's] original history. [...] It is disquieting [that in the RLC case] the DOJ appears to have jumped on the charge-the-parent bandwagon, bringing a bribery case against a parent without alleging any involvement by the parent in those violations. One can only speculate that it did so because it had no jurisdiction over the foreign subsidiary itself, given that it also did not allege any act by the subsidiary in U.S. territory. However, as always, the maxim that bad facts make bad law applies, and evidentiary weaknesses cannot excuse the distortion of the statute's previously clear and reasonable allocation of responsibility. ${ }^{30}$

While many enforcement actions against parent companies based on the conduct of foreign subsidiaries contain sparse allegations about the parent company itself, it is worth noting that a few enforcement actions do advance a plausible legal basis to hold the parent company liable for foreign subsidiary conduct by articulating so-called alter ego factors. For instance, an enforcement action against software company PTC based on travel and entertainment benefits provided to alleged Chinese "foreign officials" by foreign subsidiaries contained the following findings concerning the overlapping nature of the foreign subsidiary and the parent company:

- PTC exercised substantial control over PTC-China by creating functional reporting lines, approving PTC-China's key decisions, and setting PTC-China's business and financial goals.

- Both the Hong Kong and Shanghai subsidiaries shared common 
directors, all of whom were senior members or officers of PTC's legal and finance departments.

Based on these factors, the government found: "under applicable agency principles, PTC-China and its employees acted as agents of PTC during the relevant time and were acting within the scope of their authority and for the benefit of PTC when participating in the bribery scheme."31

In sum, two main root causes of scrutiny and enforcement are parent

- subsidiary issues and expansive enforcement theories related to corporate hierarchies as well as the previously discussed respondeat superior principle.

\section{Realities of the global marketplace}

Whereas the above root causes of scrutiny and enforcement were generic, the specific realities of doing business in the global marketplace are also often root causes of scrutiny and enforcement. Referring back to the guiding question, do companies subject to the FCPA do business in foreign markets:

- intent on engaging in bribery as a business strategy and without a commitment to compliance; or

- with a commitment to compliance, yet subject to unrealistic legal standards and/or difficult and complex business conditions.

A close read of enforcement actions reveals that the origins of enforcement are often the latter category. In other words, business organizations subject to the FCPA and related laws must navigate difficult and challenging business conditions replete with trade barriers including customs procedures; import/export documentation and inspection requirements; arcane and complex licensing and certification requirements; quality standards that require product testing and inspection visits; and foreign government procurement policies. These conditions and barriers are seldom transparent and local law or practice may require a third party to navigate these bureaucracies. Using the below visual as guidance, well-intentioned companies doing business in many foreign countries are often funneled into an arbitrary world of lowpaying civil servants who oversee "red tape" bureaucracies and may 
seek to supplement their often meager government salaries through payments common and seemingly condoned in the foreign country.
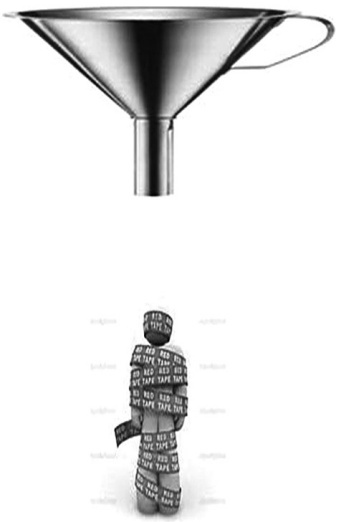

For instance, if a company wants to allow public access to its buildings in China, it must obtain a fire safety certificate and the process has been described as follows:

To obtain a fire-safety certificate from a local fire department, a business owner must pass five 'checkpoints' in a complicated and lengthy administrative process. Each checkpoint is guarded by officials in charge of site inspections and reviewing construction blueprints, equipment and contingency plans. Bribes considerably expedite the process that officials might otherwise draw out for weeks, months or years. Bribes range from a few thousand yuan to hundreds of thousands, per official, depending on their rank and the size of the project. But money isn't everything - some officials must be wined and dined or given luxury cigarettes. Others request the services of prostitutes. ${ }^{32}$

Want to build a manufacturing facility in Russia? No problem, but a business organization may need 240 separate licenses and permits. ${ }^{33}$ The risk formula is really not complex recognizing that the FCPA and related laws are implicated when real people, operating in real business environments, have real points of contact, with real "foreign officials."

- Foreign trade barriers, distortions and business conditions create bureaucracy.

- Bureaucracy creates points of contact with foreign officials.

- Points of contact with foreign officials create discretion. 
- Discretion creates the opportunity for a foreign official to misuse their position by making bribe demands.

To successfully complete the risk assessment skills exercise in Chapter 6 , it is critical to understand this basic, yet often overlooked, reality of doing business in the global marketplace. As discussed in greater detail in Chapter 6, while Transparency International's “Corruption Perception Index" tends to be a popular metric for business organizations to riskrank countries, a better alternative may be the World Bank's "Ease of Doing Business" ranking which categorizes countries based on factors such as the ease of starting a business, obtaining permits, and otherwise dealing with regulatory officials. Not surprisingly, there is a clear overlap between foreign government bureaucracy and corruption and countries that have lower regulatory burdens tend to be less corrupt and countries with higher regulatory burdens tend to be more corrupt. ${ }^{34}$

The following enforcement actions highlight how foreign business conditions are often the root cause of enforcement actions.

- Helmerich \& Payne, an oil and gas drilling company, resolved an enforcement action based on alleged payments made by second-tier subsidiaries to various officials and representatives of the Argentine and Venezuelan customs services in connection with the importation and exportation of goods and equipment. As alleged, the payments were made through agents or customs brokers, involved low dollar amounts, and were "made on an infrequent basis." 35

- Seed company Delta \& Pine Land Company resolved an enforcement action based on alleged payments made or offered by a subsidiary to officials of the Turkish Ministry of Agricultural and Rural Affairs to obtain government reports and certifications such as farm field inspections that were necessary to operate in Turkey. ${ }^{36}$

- Tyson Foods, a poultry producer, resolved an enforcement action based on alleged payments made by a subsidiary to Mexican veterinarians. As alleged, the veterinarians were required to be onsite at the company's facility to certify product for export and certain veterinarians were allowed to charge the facility for their work (to supplement their government salary) while certain other veterinarians were not. The resolution documents did not provide any detail how the payments sought to influence the veterinarians or suggest that the products were not qualified for export. ${ }^{37}$ 
Enforcement actions based on alleged conduct in high-growth markets like India and Nigeria further demonstrate how foreign business conditions often facilitate passive bribery. For instance, doing business in India often requires companies to navigate the "license raj" and practitioners have stated:

As with other countries, a host of regulatory hurdles exists in India, including the need to obtain permits, licenses, and other regulatory approvals and to pay various application and registration fees. These types of low-level transactions provide opportunities for bribery. ${ }^{38}$

According to survey data, $54 \%$ of Indians pay bribes to receive basic services and India's Chief Economic Advisor has acknowledged that "harassment bribery is widespread in India." ${ }^{9}$ Recent enforcement actions concerning business conduct in India demonstrate that harassment bribery is common and that business organizations operating in India face - just as locals do - difficult conditions simply to get things done.

- Mondelez International, a snack and beverage company, resolved an enforcement action in connection with an agent retained by an acquired entity to interact with officials to obtain approximately 30 licenses and approvals for a chocolate factory. ${ }^{40}$

- $\mathrm{AB}$ InBev, a beverage and brewing company, resolved an enforcement action based in part on it needing the approval of a state "Excise Minister" to extend brewery production time beyond 8 hours a day. ${ }^{41}$

- Diageo, a spirits company, resolved an enforcement action based in part on alleged payments made by a subsidiary in connection with product label registration and securing favorable product placement and promotion at state-owned liquor stores. ${ }^{42}$

- Wabtec, a brake manufacturer, resolved an enforcement action based on alleged payments made by a subsidiary in connection with scheduling pre-shipping product inspections, issuance of product delivery certificates, and tax audits. ${ }^{43}$

- Baker Hughes, an oilfield services company, resolved an enforcement action based in part on alleged payments made by a subsidiary to obtain shipping permits. ${ }^{44}$ 
In Nigeria, 142 separate signatures may be needed to clear cargo through customs and it is thus not surprising that several enforcement actions have involved business interactions with the notoriously corrupt Nigerian Customs Service (NCS) including a coordinated enforcement action involving several companies in the oil and gas industry. ${ }^{45}$ These parallel actions largely involved alleged payments to NCS officials in connection with securing temporary importation permits for oil drilling rigs. In addition, the actions also involved payments through a freight forwarder to NCS officials to expedite the importation of goods and equipment into Nigeria and payments to circumvent customs clearance processes with respect to importation of certain tools and materials. ${ }^{46}$

The above root causes of enforcement all involved business organizations having points of contact with alleged "foreign officials" in connection with rather boring and mundane aspects of business. Yet another foreign business condition that often serves as a root cause of scrutiny and enforcement is the inability of a company to sell its product or service without a government-issued license. For instance, the root cause of enforcement actions against beauty and healthcare products companies Avon and $\mathrm{Nu}$ Skin Enterprises was the same: China prohibited direct selling of such products; the companies needed a government issued-license to do so; and in connection with securing the license various things of value were allegedly provided to regulatory officials. ${ }^{47}$ Interestingly, several years prior to the enforcement action, $\mathrm{Nu}$ Skin publicly disclosed the following risks associated with direct selling in China:

Our operations in Mainland China are subject to significant regulatory scrutiny. The legal system in Mainland China provides government authorities broad latitude to conduct investigations and many Chinese regulations, including those governing our business, are subject to significant interpretation, which may vary from jurisdiction to jurisdiction. Because of significant government concerns in Mainland China regarding improper direct selling activities, government regulators closely scrutinize activities of direct selling companies and activities that resemble direct selling. The government in Mainland China continues to inspect and interview the direct selling industry on a regular basis, which has and may continue to increase regulatory scrutiny of the industry and our business. ${ }^{48}$

Another frequent root cause of scrutiny and enforcement are forced business relationships that companies are often required to have pursuant to foreign law, regulation or practice. In other words, in certain countries and in certain sectors, a seller of products or services can't 
have a direct relationship with an interested buyer, but is required to work through a third party (whether an agent, representative, distributor, or joint venture partner) to interact with customers and potential customers. As discussed in greater detail in Chapter 3, because of the FCPA's third-party payment provisions, these relationships often serve as the root cause of enforcement as demonstrated by the following actions:

- Akamai Technologies resolved an enforcement action based on conduct in China pursuant to circumstances in which "under China's regulatory system, [the company was] required to contract with third-party channel partners to deliver its services to end customers." ${ }^{49}$

- Telia, a telecommunications company, resolved an enforcement action based on conduct in Uzbekistan pursuant to circumstances in which "before entering the Uzbek market, company management understood that they were required to have a Foreign Official as a 'local partner' to conduct business in Uzbekistan."

- Conglomerate company Hitachi resolved an enforcement action based on conduct in South Africa pursuant to circumstances in which companies that partnered with a local black-owned entity enjoyed preferential status in government procurement and the local entity turned out to be a front for the country's ruling political party. ${ }^{51}$

Consider also the circumstances in which various oil and gas companies operate in Angola, the second largest oil-producing country in Africa. The sector is overseen by Sonangol (a state-owned/state-controlled enterprise) pursuant to local content regulations which require foreign companies to partner with Angolan companies. Given these circumstances, it is not surprising that this requirement has served as the root cause of several enforcement actions including against oil and gas service companies Halliburton and Weatherford International.

Even if business is legitimately secured in a foreign country, a dysfunctional foreign government may refuse to pay a company amounts legally owed providing yet another root cause of enforcement. For instance, several enforcement actions regarding conduct in Venezuela arose because the government was unable to pay its bills and alleged "foreign officials" at the state-owned oil company offered to pay outstanding bills (among a stack of many no doubt) in exchange for things of value. ${ }^{52}$ 
Likewise, a main feature of the \$54 million enforcement action against agriculture company Archer Daniels Midland Co. (ADM) and related entities was that ADM and its shareholders were victims of a corrupt Ukraine government which refused to release value-added tax refunds legitimately owed to the company. In the words of the government "the Ukrainian government did not have the money to pay VAT refunds that it owed to companies that sold Ukrainian goods outside of Ukraine" and the "Ukrainian government determined to delay paying the VAT refunds owed or did not make any refunds payments at all."53 One of the most dubious enforcement actions of all time was against Vitusa Corp. and its president under circumstances in which the company entered into a lawful contract to sell milk powder to the Dominican Republic government. According to the government:

Although Vitusa delivered the milk powder to the Government of the Dominican Republic, the Dominican government did not pay Vitusa promptly for the milk powder received and, in fact, maintained an outstanding balance due for an extended period of time. Vitusa, therefore, made various efforts to collect the outstanding balance due, including contacting officials of the United States and Dominican Governments to obtain their assistance in securing payment in full.

Perhaps the Vitusa and ADM enforcement actions would not have occurred if foreign government were not dysfunctional. Perhaps the Halliburton and Weatherford enforcement actions would not have occurred if the companies were not subject to local content requirements in Angola. Perhaps the Akamai Technologies enforcement action would not have occurred if the company could have delivered its services directly to customers in China. Perhaps the AB InBev enforcement action would not have occurred if the company could have decided its production hours without Indian government approval.

To repeat, an examination of typical root causes of scrutiny and enforcement is not meant to excuse the conduct, but rather to understand how and why the conduct occurred in the first place. Against the backdrop of the simplistic "just don't bribe" narrative advanced by some is the fact that the overwhelming majority of business organizations subject to the FCPA and related laws do business in the global marketplace with a commitment to compliance yet subject to unrealistic legal standards and/or difficult and complex business conditions that result in real people, operating in real business environments, having real points of contact, with real "foreign officials." 
From a compliance standpoint, it is imperative to understand and appreciate this basic reality of doing business in the global marketplace in order to minimize risk. Moreover, from a policy standpoint it is important to understand and appreciate this reality because ad hoc enforcement alone of FCPA and related laws against payors of alleged bribes will not reduce bribery and corruption. Rather, bribery and -corruption is best reduced through a reduction in foreign trade barriers, distortions and business conditions that often put business organizations in contact with alleged "foreign officials."

The omnipresent risk of doing business in the global marketplace discussed in this section is not the only reason why a diverse group of professionals need skills to spot risk under the FCPA and related laws. As the next section highlights, professionals also need the ability to spot risk because the failure to do so can have wide-ranging negative financial consequences for business organizations above and beyond any enforcement action brought by law enforcement.

\section{"Ripple effects" of scrutiny and enforcement}

Obviously one reason to comply with the FCPA and related laws is because non-compliance can expose a company to an actual enforcement action brought by law enforcement. However, enforcement action settlement amounts are often only a relatively minor component of the overall financial consequences that often occur because of the "ripple effects" of scrutiny and enforcement. To guide your learning on this important topic, use the below visual and think of the drop of water as being scrutiny under the FCPA or related laws or an actual enforcement action brought by law enforcement.

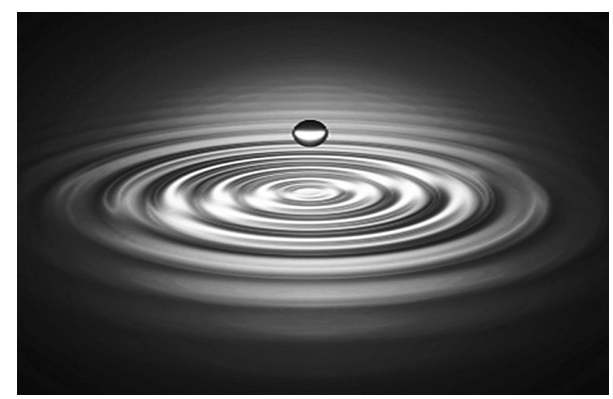


This drop of water is going to cause numerous "ripple effects" just as scrutiny and enforcement under the FCPA and related laws often cause numerous "ripple effects" ranging from: pre- and post-enforcement action professional fees; and expenses to other negative impacts on a company's business operations and strategy from market capitalization, cost of capital, merger and acquisition activity, and impeding or distracting a company from achieving other business objectives. In addition, scrutiny and enforcement can also expose corporate directors and executives to private civil suits. Moreover, with increasing frequency business organization scrutiny and enforcement is being used "offensively" by others to achieve a business objective or to further advance a litigating position.

Discussion of these many other "ripples" is intended to shift the compliance conversation away from a purely legal issue to its more proper designation as a general business issue that needs to be on the radar screen of various professionals who can assist in risk management and who should view the importance of compliance more holistically and not merely through the narrow lens of actual enforcement actions.

\section{The three buckets of financial exposure}

An obvious reason to comply with the FCPA and related laws is that non-compliance can expose a business organization to a criminal or civil enforcement action by government law enforcement. However, settlement amounts in an actual enforcement action are often only a relatively minor component of the overall financial consequences that can result from scrutiny or enforcement and the below visuals highlight the "three buckets" of financial exposure including the typical ratios between each separate category.

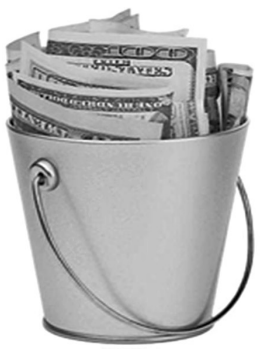

Pre-Enforcement Action Professional Fees and Expenses

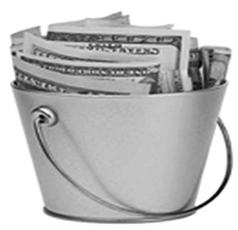

Enforcement Action Day

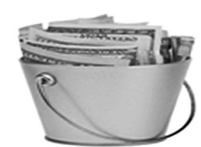

Post-Enforcement Action Professional Fees and Expenses 


\section{Pre-enforcement action professional fees and expenses}

Every instance of business organization scrutiny has a point of entry in other words a set of facts which give rise to the scrutiny in the first place. This point of entry is often the beginning of a long and expensive journey for a business organization and the first bucket of financial exposure is pre-enforcement action professional fees and expenses. For instance, beauty products company Avon disclosed that it was conducting an FCPA internal investigation regarding compliance in China. ${ }^{54}$ As is typical, the investigation soon spread to other countries and over the next several years the company disclosed approximately $\$ 550$ million in pre-enforcement action professional fees and expenses - a figure that far exceeded the \$135 million settlement amount in the actual enforcement action. Wal-Mart's scrutiny resulted in even higher pre-enforcement action professional fees and expenses after it disclosed that it was conducting an internal investigation concerning certain permitting, licensing and inspection issues in Mexico. Thereafter, Wal-Mart's investigation likewise expanded and the company's disclosed pre-enforcement action professional fees and expenses, as well as compliance enhancement costs, skyrocketed to approximately $\$ 880$ million. ${ }^{55}$

It is not just large multinationals that are the subject of high-profile scrutiny that spend millions of dollars in pre-enforcement action professional fees and expenses. For instance, scientific instrument maker Bruker Corp. resolved an enforcement action for \$2.2 million, but disclosed approximately $\$ 22$ million (a 10:1 ratio) in pre-enforcement action professional fees and expenses. Likewise, telecommunications company Veraz Networks resolved an enforcement action for \$300,000, but disclosed approximately \$3 million (a 10:1 ratio) in pre-enforcement action professional fees and expenses. Similarly, oil and gas company Hyperdynamics resolved an enforcement action for \$375,00o, but disclosed approximately \$12.7 million (a 33:1 ratio) in pre-enforcement action professional fees and expenses. Even more dramatic, oil and gas services provider NATCO Group resolved an enforcement action for $\$ 65,000$, but disclosed approximately $\$ 11$ million (a 170:1 ratio) in preenforcement action professional and expenses and also experienced cash-flow problems as a result of its scrutiny. ${ }^{56}$

Comparing pre-enforcement action professional fees and expenses to settlement amounts is not possible in all cases as companies have different disclosure requirements and practices. However, where a com- 
parison is possible it is clear that pre-enforcement action professional fees and expenses are typically the greatest financial consequence to a business organization resolving an enforcement action. The question is why are pre-enforcement action professional fees and expenses so expensive?

Resolution documents from an enforcement action against telecommunications company Alcatel-Lucent provide some insight. In the resolution documents, it was noted:

At the request of the government, [Alcatel-Lucent] undertook a 'Global Review' to evaluate its relationship with agents, interactions with government officials, and gifts, travel and entertainment provided in countries around the world. [...] In particular, Alcatel-Lucent and its outside counsel conducted investigations of 34 countries around the world to uncover potential misconduct. The internal investigation examined Alcatel-Lucent's agent and consultant approval, review, and termination processes, the activities of a number of terminated agents, and the knowledge and involvement of senior management in any potential wrongdoing. This effort was closely coordinated with the government. [...] [As part of its agent and consultant approval process review], Alcatel-Lucent retained an independent investigative firm to review all of Alcatel-Lucent's 300 then-existing agents and consultants. [...] Additionally, [...] Alcatel-Lucent commenced a review of its Board of Directors' and other senior management's knowledge of, and involvement in, any of the wrongdoing. As part of this review, interviews were conducted of 26 individuals who were either current high-ranking members of Alcatel-Lucent's management, former high-ranking members of Alcatel's management, or were in a position to provide information relevant to the review. Alcatel-Lucent and its counsel also reviewed documents collected from these individuals. [...] Overall, Alcatel-Lucent's outside counsel interviewed over 330 witnesses as part of these investigations, collected data from 201 individuals, and reviewed over 2 million documents, of which over 200,000 documents were produced to the government. ${ }^{57}$

As hinted at above, a main reason why pre-enforcement action professional fees and expenses are typically the most expensive aspect of scrutiny and enforcement is because of the "where else" question. The "where else" question generally happens as follows. A business organization becomes the subject of scrutiny for conduct that allegedly occurred in country $x$. Before the enforcement agencies resolve any enforcement action concerning the conduct in country $x$, they 
will often ask "where else?" In other words, if the conduct giving rise to scrutiny occurred in country $x$, how do the enforcement agencies know that similar conduct did not also occur in countries $a$, $b, c, d$, etc. Thus, the "where else" question typically asked results in a business organization conducting a much broader review of its operations.

Because cooperation with the government's investigation is an important factor that the enforcement agencies consider in deciding whether to bring an enforcement action, and if so on what terms, business organizations invariably, yet perhaps reluctantly, accept counsel's recommendation to broaden the internal investigation to best demonstrate cooperation. What happens next is that a business organization is paying for a team of lawyers (often accompanied by forensic accountants and other specialists) to travel around the world to answer the "where else" question even though the organization's scrutiny probably began with specific conduct in a specific country. For instance, the Magyar Telekom enforcement action focused on business conduct in Macedonia and Montenegro, but in resolving its scrutiny the company conducted a "thorough global internal investigation concerning bribery and related misconduct." ${ }^{2}$ Likewise, the Tenaris enforcement action focused on business conduct in Uzbekistan, but in resolving the action, law enforcement cited the company's "voluntary investigation of [its] business operations throughout the world."

The "where else" question may even be asked in instances of scrutiny focused on conduct in foreign subsidiaries that comprise a meaningless percentage of the company's overall operations. For instance, the Tyson Foods enforcement action focused on conduct in Mexico involving a subsidiary company that "comprised less than one percent of Tyson's global net sales." Even though approximately 90\% of Tyson's sales were domestic, in resolving the enforcement action Tyson "subjected to rigorous FCPA reviews" all of its wholly-owned production facilities, including those located outside of Mexico.

In short, a key take-away point is that scrutiny and enforcement under the FCPA and related laws will probably result in pre-enforcement action professional fees and expenses that far exceed settlement amounts in an actual enforcement action. Even though this is the factual take-away point, query whether FCPA and related scrutiny have simply turned into a boondoggle for many in FCPA Inc. and 
related industries. For instance, when scrutiny is prompted by board of director or senior executive conduct that raises the possibility of a culture of corruption within the organization, the "where else" question would seem like a legitimate law enforcement question. However, an FCPA practitioner (formerly an SEC FCPA enforcement attorney) stated as follows regarding the "where else" question:

Q: What percentage of FCPA enforcement actions that you have been involved in have resulted in the 'where else' question being asked?

A: In my time as a regulator at the Securities and Exchange Commission's Division of Enforcement and in private practice, the 'where else' question has been asked in virtually every single FCPA matter in which I have been involved. I have asked it and it has been asked of me.

Q: Do you believe the 'where else' question was appropriate in these instances?

A: In some instances it was entirely appropriate for the SEC, the DOJ, and other regulators to ask the 'where else' question. In others, however, the allegations did not support a 'where else' question and it appeared to be more of a fishing expedition and boiler plate question than a well-reasoned question under the facts. 'Where else' is a reasonable and appropriate question when the alleged misconduct appears to be systemic and/or the company under investigation appears to lack the controls necessary to prevent the payment of bribes to foreign government officials. It is not, however, an appropriate question where it is intended to force companies to conduct multi country internal investigations with little more than the uninformed hunch of a government official who has little or no experience in how businesses work around the world.

That the "where else" question is asked in the absence of any meaningful check or judicial oversight also raises a host of problematic policy issues. For instance, FCPA attorneys to whom the "where else" question is posed have little incentive to pushback as the question often leads to multi-year, multi-country billing bonanzas. As Forbes noted in an article titled "The Bribery Racket":

A company that suspects bribery overseas hires a battery of lawyers, accountants and investigators who may then report any findings to Justice in hopes of some undefined leniency. More likely, the company pays out huge fines and then hires more lawyers as government-mandated compliance monitors, a job that can stretch into years of legal billing. ${ }^{59}$ 


\section{The Wall Street Journal observed:}

[The FCPA] has become big business for the lawyers who delve into the operations of companies in response to an investigation by the Justice Department and the Securities and Exchange Commission - or to avoid one. The result is a mini-industry of investigators and white-collar criminallaw practices. ${ }^{60}$

Likewise, an article titled "Lawyers need to brake their bribe-case gravy train" observed:

Lawyers need to pull the brake on their bribery-probe gravy train. [...] Wasteful scorched-earth legal tactics inflate costs, while potentially ruinous U.S. penalties make companies scared to skimp. Smarter lawyering could slow the runaway spending. Scrutiny under the FCPA typically throws multinationals into attorney-hiring overdrive. Having legal eagles delve into corporate innards helps a company look cooperative and thereby win leniency from the government. [...] Not only does the prospect of enormous fees encourage lawyers running an investigation to engage in overkill. A company's officers also don't want to be seen to cut corners or get in the attorneys' way. The usual healthy corporate tendency to police costs carefully doesn't apply. ${ }^{61}$

Relevant to pre-enforcement action professional fees and expenses, it was notable that the DOJ's FCPA Unit Chief called out the industry at an American Bar Association event and suggested that FCPA counsel often seeks to overdo it through a global search of operations for problematic conduct. Specifically, the FCPA Unit Chief discussed a case in which a company and its professional advisors came to a meeting with a global search plan and he said "no, no, no, that is not what I want."62 Thereafter, the lawyers and other professional advisors in the room "looked unhappy," but the general counsel of the company was happy. Likewise, against the backdrop of eye-popping pre-enforcement action professional fees and expenses, the DOJ's Assistant Attorney General stated:

All too often, criticism is leveled against the Justice Department for purportedly causing companies to spend years, and many millions of dollars, investigating potential violations. This is particularly true in the FCPA context where the need for international evidence can add to the expense and burden of an investigation. [...] There is no question that some cooperating companies spend large sums of money investigating potential misconduct 
and correcting internal controls issues that allowed the misconduct to occur. The decision to incur those costs, however, is one made by those companies, not a requirement of the department. [...] Although we expect internal investigations to be thorough, we do not expect companies to aimlessly boil the ocean. Indeed, there have been some instances in which companies have, in our view, conducted overly broad and needlessly costly investigations, in some cases delaying our ability to resolve matters in a timely fashion. ${ }^{63}$

For instance, in the previously mentioned Avon enforcement action, the resolution documents contained the notable statement that the company "without [DOJ] request or guidance" and "taking into account its own business interests, expended considerable resources on a company wide review" which "at times causes unintended delays in the progress of the [DOJ's] narrower investigations." ${ }^{4}$ The government's observation about "boiling the ocean" in investigations became a sensitive topic because it implicitly called into question the decisions and motivations of FCPA Inc. participants and set off a war-of-words in the FCPA space. For instance, "defense attorneys ... balked at the idea that they're spending too much time or money on investigations they're conducting in large part for the government's sake, saying they're not willfully adding unnecessary work to an FCPA probe." ${ }^{65}$ The DOJ quickly shot back when asked about companies that "rack up massive legal bills and do massive worldwide investigations," saying "that's not us. That's the companies." ${ }^{\text {"66 }}$ Regardless of who is most at fault for the extent of pre-enforcement action professional fees and expenses in a typical instance of scrutiny, the fact remains that such expenses are often the most serious financial consequence to a business organization under scrutiny.

\section{Settlement amounts}

Failure to comply with the FCPA and related laws can obviously expose a business organization to a government enforcement action and resulting settlement demand. Because the focus of this section is the many other ripples of scrutiny and enforcement beyond settlement amounts in an actual enforcement action, this section does not discuss in detail the many legal and policy issues related to enforcement action settlement amounts. ${ }^{67}$ However, to best understand the "three buckets" of financial exposure, it is useful to nevertheless highlight certain facts and figures concerning settlement amounts and Table 1.3 ranks the largest FCPA corporate settlement amounts. 
Table 1.3 Largest FCPA settlements

\begin{tabular}{|c|c|c|}
\hline Company & Settlement amount & Year \\
\hline Siemens & $\begin{array}{l}\$ 800 \text { million } \\
\quad(\$ 450 \text { million DOJ) } \\
(\$ 350 \text { million SEC })\end{array}$ & 2008 \\
\hline Alstom & $\begin{array}{l}\$ 772 \text { million } \\
\quad(\$ 772 \text { million DOJ) }\end{array}$ & 2014 \\
\hline KBR/Halliburton & $\begin{array}{l}\$ 579 \text { million } \\
\quad(\$ 402 \text { million DOJ) } \\
(\$ 177 \text { million SEC })\end{array}$ & 2009 \\
\hline Teva Pharma & $\begin{array}{l}\$ 519 \text { million } \\
(\$ 283 \text { million DOJ) } \\
(\$ 236 \text { million SEC) }\end{array}$ & 2016 \\
\hline Telia & $\begin{array}{l}\text { \$483 million } \\
\quad(\$ 275 \text { million DOJ) } \\
(\$ 208 \text { million SEC) }\end{array}$ & 2017 \\
\hline Och-Ziff & $\begin{array}{l}\text { \$412 million } \\
(\$ 213 \text { million DOJ) } \\
(\$ 199 \text { million SEC) }\end{array}$ & 2016 \\
\hline Total & $\begin{array}{l}\text { \$398 million } \\
\quad(\$ 245 \text { million DOJ) } \\
(\$ 153 \text { million SEC })\end{array}$ & 2013 \\
\hline VimpelCom & $\begin{array}{l}\text { \$398 million } \\
(\$ 230 \text { million DOJ) } \\
(\$ 168 \text { million SEC })\end{array}$ & 2016 \\
\hline Alcoa & $\begin{array}{l}\text { \$384 million } \\
\quad(\$ 209 \text { million DOJ) } \\
(\$ 175 \text { million SEC) }\end{array}$ & 2014 \\
\hline Snamprogetti/ENI & $\begin{array}{l}\text { \$365 million } \\
\quad(\$ 240 \text { million DOJ) } \\
(\$ 125 \text { million SEC) }\end{array}$ & 2010 \\
\hline
\end{tabular}

The figures in Table 1.3 represent net FCPA settlement amounts after accounting for certain credits or deductions in a few enforcement actions involving foreign companies. For instance, in addition to the amounts listed above: Siemens also paid approximately $\$ 850$ million in related German law enforcement actions, ${ }^{68}$ Telia also paid approximately $\$ 483$ million in related Swedish and Dutch law enforcement actions ${ }^{69}$ VimpelCom also paid approximately $\$ 398$ million in a related Dutch law enforcement action ${ }^{70}$ and Teva also paid approximately $\$ 22$ 
million in a related Israeli law enforcement action. ${ }^{71}$ In fact, several of the largest FCPA enforcement actions of all-time began, not with U.S. law enforcement investigations, but foreign law enforcement investigations.

For most of the FCPA's history, business organizations with exposure could sleep well at night after resolving a U.S. enforcement agency action. However, the landscape has changed and in the modern era U.S. enforcement actions are often just one consequence of scrutiny and enforcement. After resolving a corporate FCPA enforcement action the company may also become the subject of a foreign law enforcement investigation based on the same core conduct alleged in the FCPA enforcement action. After all, the U.S. action was based on allegations that the company, or someone on its behalf, made payments to a foreign official to obtain or retain business. Given the ease with which information now flows and the growing interest in cracking down on bribery and corruption, FCPA enforcement actions are frequently read around the world by foreign media, foreign-based non-governmental organizations, and even foreign governments themselves. Thus, it is not surprising that when the dust settles on corporate FCPA enforcement actions many remain interested in the conduct, including the foreign governments whose alleged "foreign officials" were implicated in the conduct at issue.

For instance, a few days after Ralph Lauren Corporation resolved an FCPA enforcement action based on the conduct of its subsidiary in Argentina, the head of Argentina's tax agency wrote to the U.S. Ambassador to Argentina stating that it was necessary for the Argentine government to have names and more detailed information about the alleged bribery to aid in a newly launched criminal investigation into the matter. ${ }^{72}$ Likewise, tobacco companies Alliance One International Inc. and Universal Corporation resolved FCPA enforcement actions principally based on allegations of improper payments to Thai government officials to secure contracts with an alleged Thai government agency for the sale of tobacco leaf. ${ }^{73}$ Soon thereafter, Thai law enforcement officials began an investigation of the conduct at issue. ${ }^{74}$ Regarding law enforcement cooperation in international bribery schemes, the DOJ has stated:

An international approach is being taken to combat an international criminal problem. We are sharing leads with our international law enforcement counterparts, and they are sharing them with us.

It is safe to say that we are cooperating with foreign enforcement on foreign bribery cases more closely today that at any time in history. 
In fact, one reason for the typically large pre-enforcement professional fees and expenses (as well as post-enforcement action professional fees and expenses highlighted next) is that business organizations under scrutiny often hire legal counsel and other professional advisors in multiple jurisdictions to interact with and report to the various law enforcement agencies investigating and prosecuting the underlying conduct.

Settlement amounts in an actual enforcement action will obviously be specific to the unique facts and circumstances at issue and it would be inaccurate to conclude from the above top 10 list of FCPA settlements that all corporate enforcement actions involve nine-figure settlement amounts. However, it is worth highlighting that settlement amounts have come a long way in a short amount of time. For example, in 2007 Baker Hughes resolved the largest FCPA enforcement action of all time by agreeing to pay a combined $\$ 44$ million in DOJ and SEC enforcement actions. ${ }^{75}$ According to the DOJ, the company made approximately $\$ 4.1$ million in improper payments through an agent in connection with a "giant gas and oil field" in Kazakhstan. The DOJ's sentencing guidelines calculation noted that the "benefit received or to be received [from the alleged improper conduct was] approximately \$19 million." The related SEC enforcement action against Baker Hughes was based on the same core conduct and the SEC's stated:

Baker Hughes paid approximately $\$ 5.2$ million to two agents while knowing that some or all of the money was intended to bribe government officials, specifically officials of State-owned companies, in Kazakhstan. ... Baker Hughes engaged the agent and was awarded an oil services contract in the Karachaganak oil field in Kazakhstan that generated more than \$219 million in gross revenues from 2001 through 2006.

In addition, the SEC stated:

- Baker Hughes authorized commission payments of nearly \$5.3 million to an agent (who worked in Kazakhstan, Russia and Uzbekistan) under circumstances in which the company failed to determine whether such payments were, in part, to be funneled to government officials in violation of the FCPA;

- in Indonesia Baker Hughes paid certain freight forwarders to import equipment into Indonesia using a "door-to-door" process under circumstances in which the company failed to adequately 
assure itself that such payments were not being passed on, in part, to Indonesian customs officials;

- in Nigeria Baker Hughes authorized payments to certain customs brokers to facilitate the resolution of alleged customs deficiencies under circumstances in which the company failed to adequately assure itself that such payments were not being passed on, in part, to Nigerian customs officials; and

- $\quad$ in Angola Baker Hughes paid an agent more than \$10.3 million in commissions under circumstances in which the company failed to adequately assure itself that such payments were not being passed on to employees of Sonangol, Angola's state-owned oil company, to obtain or retain business in Angola.

Since the then record-setting Baker Hughes enforcement action, comparatively minor enforcement actions, per the enforcement agencies' own allegations, have been resolved for larger settlement amounts. For instance, the Diebold enforcement action focused primarily on excessive travel and entertainment and government allegations that company subsidiaries provided various things of value (such as Las Vegas sightseeing, a dance show, a Grand Canyon tour, a Universal Studios tour and a Napa Valley tour) to alleged Chinese and Indonesian "foreign officials" at state-owned banks. As to the core conduct, the DOJ's sentencing guidelines calculation referenced a "value of benefit received [from the alleged improper conduct] of more than $\$ 7$ million."

In other words, per the enforcement agencies' own allegations, the Diebold enforcement action involved significantly less egregious conduct than the Baker Hughes enforcement action. Yet the combined \$48 million settlement amount in the Diebold was more than the record-setting \$44 million Baker Hughes enforcement action just a short time ago. As FCPA practitioners have rightly observed: "an unmistakable characteristic of [recent] FCPA enforcement is that the market rate for resolving a corporate FCPA enforcement action [has] spiked precipitously."76

\section{Post-enforcement action professional fees and expenses}

The negative financial consequences of scrutiny and enforcement continue even after enforcement action day because of post-enforcement action professional fees and expenses. Many corporate enforcement actions are resolved through non-prosecution agreements or deferred 
prosecution agreements (a resolution vehicle gaining acceptance in other countries as well) and a common clause in such agreements is a requirement that the company resolving the enforcement action report to the enforcement agencies during the typical 18 month to 3 year term of the agreement regarding, among other things, its implementation of a compliance program and its ongoing compliance efforts. ${ }^{77}$ Such a requirement may seem simple and straightforward; however it often involves internal reviews, follow-up reviews and written reports and typically costs a business organization millions of dollars in additional professional fees and expenses. While post-enforcement action professional fees and expenses tend to be the smallest of the "three buckets" of financial exposure, such expenses can quickly mount even in garden-variety FCPA enforcement actions.

In addition to the above standard post-enforcement action compliance obligations, the enforcement agencies have also imposed "enhanced compliance obligations" on certain companies as a condition of settlement. For instance, healthcare company Johnson \& Johnson (J\&J) resolved an enforcement action focused on subsidiary conduct in Greece, Poland, and Romania. The enforcement action was resolved through a DPA and the government specifically noted: "J\&J had a pre-existing compliance and ethics program that was effective and the majority of problematic operations globally resulted from insufficient implementation of the J\&J compliance and ethics program in acquired companies." ${ }^{78}$ The DPA contained the standard compliance obligations found in a typical FCPA DPA, but also included "enhanced compliance obligations" that I\&J was required to abide by during the three-year term of the agreement. Even though the government stated that J\&J, as part of the voluntary disclosure and cooperation process, "conducted an extensive, global review of all of its operations to determine if there were problems elsewhere," the "enhanced compliance obligations" nevertheless required J\&J to "conduct risk assessments of markets where [the company] has government customers and/or other anticorruption compliance risks on a staggered, periodic basis."

In what seemed like an FCPA Inc. full employment act, the government also required J\&J to "identify no less than five operating companies that are high risk for corruption because of their sector and location and [...] conduct FCPA audits of those operating companies at least once every three years." As stated in the DPA, "FCPA audits of other operating companies that pose corruption risk shall occur no less than once every five years" and "each FCPA audit should include" the following: 
(i) on-site visits by an audit team comprised of qualified auditors who have received FCPA and anticorruption training; (ii) where appropriate, participation in the on-site visits by personnel from the compliance and legal functions; (iii) review of a statistically representative sample appropriately adjusted for the risks of the market, of contracts with and payments to individual health care providers; (iv) creation of action plans resulting from issues identified during audits; and (v) where appropriate, feasible, and permissible under local law, review of the books and records of distributors which, in the view of the audit team, may present corruption risk.

From a policy perspective, were the "enhanced compliance obligations" truly necessary given the government's conclusion that J\&J already had generally "effective" compliance policies and procedures and given that the company, prior to resolving the enforcement action, already "conducted an extensive, global review of all of its operations to determine if there were problems elsewhere"? Or were these "enhanced compliance obligations" an example of a business organization being required by the government to engage in fishing expeditions when the company already went fishing just for the sake of going fishing again? If so, the "enhanced compliance obligations" represented a boundless and unconstrained government-required transfer of shareholder wealth to FCPA Inc. Such fishing expeditions are of course lucrative for FCPA Inc. and hence one reason why few in the industry have raised concerns about "enhanced compliance obligations" or other post-enforcement action compliance requirements.

In addition to standard post-enforcement action compliance requirements or "enhanced compliance obligations," certain companies have also been required to engage an independent compliance monitor as a condition of settlement. As noted in the FCPA Guidance, "a monitor is an independent third party who assesses and monitors a company's adherence to the compliance requirements of an agreement that was designed to reduce the risk of recurrence of the company's misconduct." The term monitor is a bit misleading as it suggests a single person. The reality is that a monitor, while a single person, is more like the conductor of a large orchestra and a monitorship can become an expensive and distracting requirement of resolving an enforcement action. FCPA practitioners have observed:

Few penalties imposed on a corporate criminal offender cause as much consternation as do compliance monitors. After the late-night crisis management meetings, after the invasive and expensive internal investigation, 
after the shakeup of senior managers, and after the protracted negotiations with federal authorities, companies just want to get back to business. They want to sell their goods and services, be profitable, invest, and grow. In short, they want to move on. Fundamentally, the corporate compliance monitor stands in the way of forgetting the past and going back to 'business as usual' - at least when it comes to obeying the law. The monitor's purpose is to see that the company follows applicable laws and regulations going forward and institutes the proper policies and procedures to help ensure compliance. Corporations will never welcome this "tail" to their criminal prosecutions. Monitorships inevitably involve significant expenditures of funds and time. ${ }^{79}$

As stated in FCPA Guidance, the enforcement agencies consider the following factors when determining whether a compliance monitor is an appropriate requirement of a corporate enforcement action: seriousness of the offense; duration of the misconduct; pervasiveness of the misconduct, including whether the conduct cuts across geographic and/or product lines; nature and size of the company; quality of the company's compliance program at the time of the misconduct; and subsequent remediation efforts.

Based on these factors, it was not surprising that Siemens (as well as certain other companies on the previously highlighted top ten FCPA settlement list) was required to engage a compliance monitor when resolving its enforcement action. The government's filing upon determining that Siemens satisfied its post-enforcement action obligations provided insight into the extent of the monitor's work and stated:

In accordance with the plea agreement, the Monitor conducted an initial review and three subsequent reviews of Siemens's anti-corruption compliance program, and documented the Monitor's findings and recommendations in four annual reports [...]. Over the course of those four years, the Monitor conducted on-site or remote reviews of Siemens' activities in 20 countries; conducted limited or issue-specific reviews in or relating to an additional 19 countries; reviewed over 51,0oo documents totaling more than 973,000 pages in 11 languages; conducted interviews of or meetings with over 2,300 Siemens employees; observed over 180 regularly scheduled company events; and spent the equivalent of over 3,00o auditor days conducting financial studies and testing. ${ }^{80}$

Siemens did not disclose its post-enforcement action professional fees and expenses, including its monitor costs, but one can safely assume 
that such fees and expenses were in the hundreds of millions of dollars and in addition to: (i) the approximate $\$ 1$ billion dollars the company spent in pre-enforcement action professional fees and expenses; (ii) the $\$ 800$ million the company paid to resolve the FCPA enforcement action; and (iii) the $\$ 850$ million the company paid to resolve the related German enforcement action.

Even in less high-profile enforcement actions monitor costs can reach into the millions of dollars. For instance, oil and gas services company Willbros Group agreed to pay approximately $\$ 32$ million to resolve an enforcement action and thereafter disclosed monitor expenses of approximately $\$ 10$ million. ${ }^{81}$ Likewise, Faro Technologies agreed to pay approximately $\$ 3$ million to resolve an enforcement action and thereafter disclosed monitor expenses of approximately $\$ 2$ million. ${ }^{82}$

Regardless of which of the "three buckets" the money falls into, the take-away point from this section is that scrutiny and enforcement under the FCPA and related laws typically result in wide-ranging negative financial consequences for a business organization, and as depicted in the below visual, settlement amounts in an actual enforcement action are often just the tip of the iceberg in terms of the company's overall financial exposure.

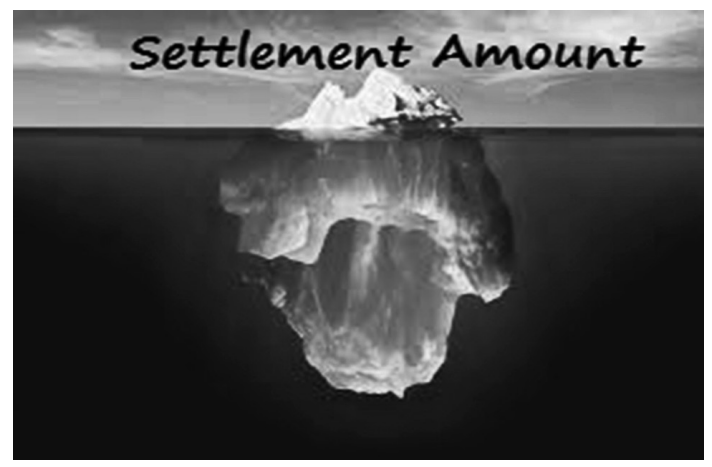

The "three buckets" of financial exposure highlighted above were all related to investigating conduct arising under the FCPA and related laws, responding to law enforcement inquiries, resolving actual enforcement actions, and abiding by post-enforcement action compliance obligations and reporting requirements. However, as next discussed there 
are also numerous other "ripples" of scrutiny and enforcement that are not as directly tied to law enforcement investigations and enforcement.

\section{Negative business effects of scrutiny and enforcement}

To review, Chapter 1 has thus far focused on why a diverse group of professionals need skills to spot risk under the FCPA and related laws. In addition to the reasons highlighted above, professionals also need skills to spot risk because the failure to do so can have a variety of negative business effects. Legal scrutiny represents uncertainty and, as depicted in the below visual, is like a cloud hanging over a business organization. Because FCPA scrutiny concerns bribery and possible criminal sanctions, the cloud hanging over the organization is black or at the very least gray.

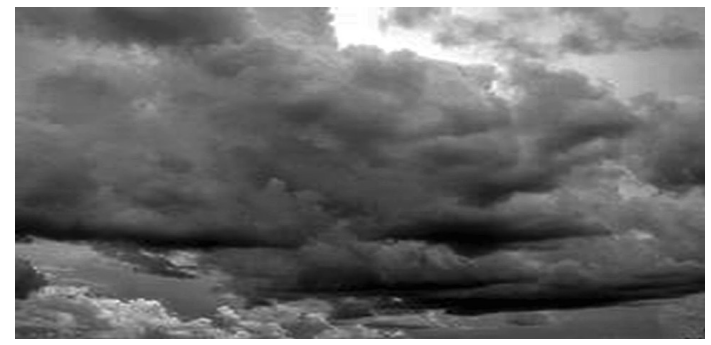

Combine this with the fact that scrutiny tends to last, on average approximately four years with longer periods possible, and it is not surprising that scrutiny often results in numerous other "ripples" for a business organization beyond those already highlighted. ${ }^{83}$ As rightly noted by an FCPA commentator: "companies [under FCPA scrutiny] get stuck in FCPA limbo. [...] The threat of FCPA enforcement [...] casts a long shadow. It darkens the future for management, shareholders, lenders, customers, and suppliers." ${ }^{" 4}$ As discussed in this section, these "ripples" can have a negative impact on a company's business operations and strategy ranging from market capitalization, credit ratings, merger and acquisition activity, and impeding or distracting a company from achieving other business objectives. Moreover, with increasing frequency scrutiny and enforcement is being used "offensively" by others to achieve a business objective or to further advance a litigating position.

It is particularly important for compliance professionals to understand and appreciate these numerous other "ripples" because their aggregate impact often exceeds even the "three buckets" of financial exposure previously highlighted. Moreover, compliance professionals often find 
themselves asking corporate management for additional resources for the compliance function. Surely, progress will be made when corporate management is warned that failure to devote sufficient resources to compliance with the FCPA and related laws can expose the organization to an actual law enforcement action and its attendant collateral effects.. Surely, progress will be made when corporate management is shown the previously highlighted top 10 list of FCPA settlements. Query, however, whether compliance professionals can best obtain the desired resources needed for compliance by highlighting the many negative business effects of scrutiny and enforcement in language that is most likely to resonate with corporate management such stock price, cost of capital, lost or delayed business opportunities, and perhaps even individual liability in related civil litigation. In other words, scrutiny and enforcement is not just a legal issue, but a business issue as well that needs to be on the radar screen of various professionals who can assist in risk management and who should view the importance of compliance holistically and not merely through the narrow lens of actual enforcement actions. It is these numerous other "ripples" of scrutiny and enforcement that are perhaps the most important reason why a diverse group of professionals need skills to spot risk and various case studies demonstrate this important, yet often overlooked, concept.

\section{Market capitalization}

Market capitalization is an important data point for investors and an important metric by which business manager performance is judged and is calculated by multiplying a company's outstanding shares by the current market price of one share. Because FCPA or related scrutiny or enforcement can impact a company's share price, a company's market capitalization is likewise impacted, as highlighted by the following examples.

Wal-Mart's scrutiny, although disclosed in an SEC filing months earlier, escalated when the New York Times published a front-page article concerning alleged conduct in Mexico. The market reacted swiftly to the Times article and the first trading day after the Times article the stock dropped $4.7 \%$ and continued a downward trend for several days erasing approximately $\$ 20$ billion in shareholder value). Shares of SciClone Pharmaceuticals Inc., a U.S.-based, China-focused specialty pharmaceutical company, plunged approximately $40 \%$ and closed down approximately $32 \%$ from its previous trading day. Such a dramatic decline in stock price is normally associated with a Chief 
Executive Officer resigning, a declaration of bankruptcy, or other crisis-like events. However, the decline in SciClone's stock price was due to the following disclosure made by the company.

SciClone was contacted by the SEC and advised that the SEC has initiated a formal, non-public investigation of SciClone. In connection with this investigation, the SEC issued a subpoena to SciClone requesting a variety of documents and other information. The subpoena requests documents relating to a range of matters including interactions with regulators and government-owned entities in China, activities relating to sales in China and documents relating to certain company financial and other disclosures. The Company [also] received a letter from the DOJ indicating that the DOJ was investigating FCPA issues in the pharmaceutical industry generally, and had received information about the Company's practices suggesting possible violations. ${ }^{85}$

Likewise, the share price of Cognizant Technology Solutions dropped approximately $13 \%$ on the day the company made the following disclosure (the same day the company also disclosed that its President has resigned):

The Company is conducting an internal investigation into whether certain payments relating to facilities in India were made improperly and in possible violation of the U.S. Foreign Corrupt Practices Act and other applicable laws. The investigation is being conducted under the oversight of the Audit Committee, with the assistance of outside counsel, and is currently focused on a small number of Company-owned facilities. The Company has voluntarily notified the United States Department of Justice (the "DOJ") and United States Securities and Exchange Commission (the "SEC") and is cooperating fully with both agencies. ${ }^{86}$

Similarly, the share price of World Acceptance Corp., a small consumer finance company operating in the U.S. and Mexico, fell approximately $12 \%$ after the company made the following disclosure (the same day the company also disclosed that it was unable to file its annual report):

The Company is conducting an internal investigation of its operations in Mexico, focusing on the legality under the U.S. Foreign Corrupt Practices Act and certain local laws of certain payments related to loans, the maintenance of the Company's books and records associated with such payments, and the treatment of compensation matters for certain employees. ${ }^{87}$ 
A company's stock price, and thus its market capitalization, can also be negatively impacted by institutional investor liquidations and investment analyst downgrades. As to the former, mutual fund Ohio National Fund disclosed the following regarding its investment in Petrofac Ltd (a U.K.-based oil and gas company with shares registered with the SEC and thus subject to the FCPA):

Petrofac Limited - Shares of U.K. based oilfield services firm Petrofac Limited declined sharply after the U.K.'s Serious Fraud Office ("SFO”) launched an investigation into bribery allegations related to the firm's past relationship with controversial Monaco-based consultancy Unaoil. While we had been constructive on the stock given its healthy pipeline of outstanding bids, strategic refocus on core assets, and prudent balance sheet deleveraging, the escalating fraud investigation seems to us a thesis changer. Over the past three years, nearly all of the SFO's investigations have led to charges being filed. Of particular concern, the executives currently running Petrofac Limited also ran the company when the alleged improprieties occurred. Any legal action against these individuals could materially impact Petrofac Limited's ability to win new business, without which the company's financial situation is tenuous. A change in circumstances requires a reassessment of the new reality, and we decided to liquidate our stake in Petrofac Limited given the rising risk profile. ${ }^{88}$

Regarding investment analyst opinions, the shares of technology company NCR Corp. fell approximately $8 \%$ after an investment analyst downgraded the company's stock to neutral from outperform because of the company's FCPA scrutiny. Among the concerns noted in the analyst's report were: "a multi-quarter investigation; potential fines and penalties from the single millions to tens of million; much of the company's share gains over the last two years came in emerging markets and such growth may be at risk if an FCPA investigation restricts current business practices; and that companies uninhibited by the FCPA, such as China-based competitors, could gain market share." ${ }^{89}$

Although investor reaction to FCPA related scrutiny and enforcement is not always as dramatic as the above examples, and even though the FCPA-induced stock price dips in the above examples were rather short lived as investors moved beyond the disclosures to focus more on long-term financial fundamentals, the take-away point here is that one negative business effect of scrutiny and enforcement is often a hit to the company's market capitalization. 


\section{Credit ratings}

A company's credit rating matters for a number of reasons. For instance, a company with a lower credit rating may be faced with a smaller pool of potential investors and thus may have to offer those investors a higher interest rate. Likewise, a company's credit rating will determine the interest rate at which the company can borrow money and certain institutional investors may be barred from owning non-investment grade bonds. Credit ratings can be impacted by FCPA and related scrutiny and enforcement and as stated by ratings agency Moody, "the wide range of potential outcomes and timing in [FCPA cases] can create substantial short-to-medium term uncertainty for credit investors, and we often view this uncertainty as credit negative." 90

Likewise, a report titled "U.S. Foreign Corrupt Practices Act - No Minor Matter" by Fitch Ratings highlighted the variety of negative effects that can arise from scrutiny and enforcement. ${ }^{91}$ The report noted that scrutiny can have ratings implications for companies with modest free cash flow and/or liquidity constraints. The report further noted that scrutiny can last for years and stated:

In the interim, corporate credit profiles, liquidity, and ratings may weaken. The fine that could be easily paid with cash on hand today might not be readily payable years down the road if a company's credit profile has weakened and liquidity becomes constrained.

The Fitch report also highlighted the significant amount of preenforcement action professional fees and expenses typically incurred by companies under scrutiny and highlighted the previously mentioned Avon matter in which the company's bond rating was downgraded owing to "expenses related to the ongoing investigation under the FCPA." 92

Although many FCPA settlements involve "large investment grade corporations whose substantial cash balances easily afford them the ability to absorb the payments with no or minimal increases in leverage," the Fitch report noted that "there have also been [FCPA] violations by non-investment grade companies." For instance, Willbros Group Inc. resolved a $\$ 32$ million enforcement action and the report noted that the company's scrutiny required "several amendments on its bank credit facility" which was reduced from $\$ 150$ million to $\$ 100$ million. 


\section{Mergers and acquisitions}

In addition to market capitalization and credit ratings, scrutiny and enforcement can also negatively impact merger or acquisition activity. Such negative effects range from terminating planned merger or acquisition activity, to restructuring the terms and conditions of the planned transaction, to reducing the expected financial benefits of the transaction.

\section{Termination}

In announcing a planned acquisition of Titan Corporation, the CEO of aerospace company Lockheed Martin Corp. stated:

Titan provides additional presence within the U.S. Government customer base and expands our competencies. Titan is an excellent fit with Lockheed Martin, and its acquisition is consistent with our disciplined growth and cash deployment strategies. Titan's outstanding record of sales growth and the quality of its workforce made this transaction very attractive to us. This workforce, together with our highly skilled people, allows us to provide more cost effective and robust solutions to customers of both companies. ${ }^{93}$

Soon thereafter however, Lockheed announced that it had "learned of allegations that improper payments were made, or items of value were provided, by consultants for Titan Corporation or its subsidiaries to foreign officials." Lockheed stated:

The allegations were identified as part of a review conducted with Titan of payments to Titan's international consultants in connection with the proposed acquisition of Titan. The alleged payments and provision of items of value, if true, raise questions concerning whether there has been a violation of the FCPA. [.. .] The review is ongoing. Titan is cooperating with this effort, as well as conducting its own review. Lockheed Martin and Titan have met with the SEC and the DOJ to discuss the allegations of improper payments. [...] Closing of the Titan transaction is subject to approval of Titan's stockholders, the absence of any material adverse change in Titan and other conditions set forth in the merger agreement. [...] Lockheed Martin will need to determine whether the conditions to the merger have been satisfied. ${ }^{94}$

Titan's scrutiny, which Lockheed could have inherited upon completion of the merger, resulted in a delay of the shareholder vote to approve the merger as well as an amended merger agreement 
extending the time period for the merger to occur. Ultimately, Titan's unresolved scrutiny caused Lockheed to abandon the merger and Lockheed stated:

Under the terms of the amended merger agreement, either party could terminate the merger agreement if Titan either (i) had not obtained written confirmation from the DOJ that the investigation of alleged FCPA violations was resolved as to Titan and the Department did not intend to pursue any claims against Titan; or (ii) Titan had not entered into a plea agreement [by a certain date] ... Titan did not satisfy either requirement. [...] The corporation declined Titan's request for a further extension. ${ }^{95}$

In announcing termination of the merger, Lockheed said that the company "made every possible effort to make this happen, but it just reached a point where we didn't want the uncertainty surrounding this to continue indefinitely." ${ }^{\prime 6}$ Termination of the merger had several adverse consequences for Titan. In addition to losing an acquirer, news of the merger termination caused Titan's shares to fall by approximately $20 \%$ and investment analysts downgraded the company's stock. Titan's scrutiny of course did not disappear and the company pleaded guilty to FCPA charges for, among other things, making more than $\$ 2$ million in payments through an agent to the election campaign of Benin's then-incumbent President. In resolving its FCPA scrutiny, Titan agreed to pay approximately $\$ 28$ million - at the time the largest FCPA settlement in history. ${ }^{97}$

Not all instances of FCPA scrutiny have as severe an impact on merger activity as in the Lockheed-Titan example. However, as demonstrated by the below examples, scrutiny and enforcement can also result in restructuring the terms and conditions of planned transactions and reduce the expected financial benefits of the transaction.

\section{Restructuring}

Consider the following circumstances regarding diagnostic company Alere Inc. and what happened when it disclosed an SEC subpoena inquiring about its foreign business practices. ${ }^{98}$ Thereafter, the company announced that it would be acquired by Abbott in a $\$ 5.8$ billion transaction. However, Alere's troubles mounted as the company announced that it would be unable to timely file its annual report because it was "continuing to conduct an analysis of certain aspects of the timing of revenue recognition, more specifically, revenue cutoff, in 
Africa and China." The company also disclosed at the same time that it "received a grand jury subpoena from the United States Department of Justice requiring the production of documents relating to, among other things, sales practices and dealings with third parties (including distributors and foreign governmental officials) in Africa, Asia and Latin America and other matters related to the U.S. Foreign Corrupt Practices Act." Alere's FCPA and related scrutiny complicated the planned acquisition by Abbott and Alere disclosed:

In recent discussions between the parties, Abbott informed Alere that it has serious concerns about, among other things, the accuracy of various representations, warranties and covenants made by Alere in the parties' merger agreement. Abbott indicated that these concerns relate to the delay in filing the [annual report] and governmental investigations previously announced by Alere. Abbott has requested information from Alere about these and other matters, citing contractual rights to receive information under the merger agreement. In the initial meeting in which Abbott expressed its concerns to Alere, as part of a discussion about potential paths forward, Abbott requested that Alere agree to terminate the merger agreement in return for a payment by Abbott to Alere in the range of between $\$ 30$ and $\$ 50$ million in respect of Alere's transaction expenses. Alere's Board of Directors promptly rejected that request. ${ }^{99}$

Alere's FCPA and related scrutiny, and whether it represented a "material adverse change" in the company's business operations giving Abbott the potential right to terminate the planned acquisition, soon became the focus of separate civil litigation requiring Alere to engage additional counsel. In the end, Alere and Abbott agreed to complete the transaction; however the deal closed for $\$ 5.3$ billion and not the originally contemplated $\$ 5.8$ billion price. Alere's scrutiny of course did not disappear and it ultimately resolved a $\$ 13$ million enforcement action (the FCPA portion of the settlement was approximately $\$ 3.8$ million). ${ }^{100}$

A planned merger involving engineering companies PBSJ Corp. and WS Atkins also provides an instructive case study for how scrutiny can negatively impact the terms and conditions of a transaction. Premerger, PBSJ disclosed scrutiny in connection with certain projects undertaken by its subsidiary. ${ }^{101}$ A few months later, PBSJ disclosed that its "Audit Committee completed the internal investigation [and] the results of that investigation suggest that FCPA violations may have occurred." Shortly thereafter, PBSJ announced that it entered into a definitive merger agreement in which WS Atkins planned to acquire 
PBSJ in an all-cash transaction. Proxy materials filed by PBSJ in connection with the merger provided an informative insight into how its scrutiny impacted the terms and conditions by which PBSJ would attempt to sell itself.

Among other things, the proxy materials disclosed how interested purchasers of PBSJ: held meetings with PBSJ's outside counsel and its in-house counsel to discuss the investigation; requested the opportunity to meet with DOJ representatives regarding the investigation; and requested access to attorney-client privileged documents regarding the investigation. ${ }^{102}$ In the end, PBSJ's board approved a merger agreement with Atkins even though PBSJ had received a higher offer from another company. However, the higher offer sought more stringent closing conditions concerning PBSJ's scrutiny and in approving Atkin's bid the proxy materials stated:

Positive factors considered by the [PBSJ] board of directors included: [...] the terms of the merger agreement and the related agreements, including: the limited number and nature of the conditions to Atkins' obligation to consummate the merger, including its willingness not to impose special conditions related to our previously disclosed FCPA investigation beyond those developments that would independently constitute a material adverse effect. ${ }^{103}$

\section{Reduced financial benefits}

Scrutiny and enforcement under the FCPA and related laws can also reduce the financial benefits expected from a merger by imposing significant post-closing expenses on the acquiring company for the target company's pre-closing scrutiny. For instance, facilities services company ABM Industries Inc. disclosed:

[The] Company [has] begun an internal investigation into matters relating to compliance with the FCPA and the Company's internal policies in connection with services provided by a foreign entity affiliated with a Linc joint venture partner. Such services commenced prior to the Company's acquisition of Linc. As a result of the investigation, the Company has caused Linc to terminate its association with the arrangement. The Company [has] contacted the DOJ and the SEC to voluntarily disclose the results of its internal investigation to date. The Company cannot reasonably estimate the potential liability, if any, related to these matters. ${ }^{104}$ 
ABM's scrutiny thus did not involve anything it did but was based on a foreign entity affiliated with a joint venture partner of a company ABM acquired. The value of the merger was approximately $\$ 300$ million and it was already reduced by the acquired company's scrutiny as ABM disclosed approximately $\$ 3.5$ million in pre-enforcement action professional fees and expenses. ${ }^{105}$ Factoring in ABM's potential exposure based on an actual enforcement action, $5 \%$ of the merger price could easily evaporate owing to the acquired company's FCPA issue.

In addition, post-enforcement action professional fees and expenses can further reduce the expected financial benefits of a merger. For instance, Alliance One International resolved an enforcement action by agreeing to pay $\$ 19.5$ million in combined fines and penalties. ${ }^{106}$ The entire enforcement action was based on the pre-merger conduct of acquired entities and pursuant to the resolution documents Alliance One was required to engage a compliance monitor for three years - a requirement that cost the company over $\$ 10$ million in postenforcement action monitoring costs.

The above examples of how scrutiny and enforcement can negatively impact merger and acquisition activity provide lessons for both an acquiring company and a target company. For an acquiring company, FCPA related due diligence of a target company should be part of the merger due diligence protocol so that potential issues can be learned in advance of closing. For a future target company, implementing the compliance policies and procedures discussed throughout this book can increase the value of the company and its attractiveness to a potential acquiring company. As further highlighted in Chapter 8, periodic assessment and continuous improvement are a component of compliance best practices, particularly when a company evolves, and one of the most dramatic ways a company can evolve - in terms of markets, products, services and personnel including third parties - is through merger and acquisition activity.

\section{Lost or delayed business opportunities}

In addition to impacting market capitalization and credit ratings and having a wide range of negative effects on merger and acquisition activity, another "ripple" of FCPA and related scrutiny and enforcement is lost or delayed business opportunities. 
For instance, Swiss logistics company Panalpina was under scrutiny for business conduct in Nigeria and in the midst of this scrutiny, during the company's annual meeting, a shareholder demanded that someone "step up and take responsibility" for the company's poor performance. In response, Panalpina's CEO stated, among other things, that "it is not easy being under investigation for two years, and [the FCPA investigation] is not making the situation any easier." ${ }^{107}$ The company's Chief Operating Officer added:

You can say the whole FCPA and Nigeria situation reflects badly on the management, but the fact is that as long as we are still involved in the investigation we will continue to lose market share, because our customers have internal regulations which prevent them from doing business with companies which are under investigation by the DOJ. As soon as this investigation is over, we will win some of this business back. Customers have told us "as soon as you have settled the FCPA, we will do business with you again."

While difficult to quantify, Panalpina's lost business opportunities during its scrutiny likely exceeded the $\$ 82$ million the company paid to resolve its scrutiny in an actual enforcement action. ${ }^{108}$ More dramatically, clients of hedge fund Och-Ziff withdrew $\$ 2.5$ billion in assets from the firm in just the month after it resolved a \$412 million enforcement action in connection with certain transactions in Africa countries. ${ }^{109}$ In addition, the enforcement action negatively impacted Och-Ziff's ability to raise additional capital as it disclosed:

Prior to the settlements, many of our funds raised capital relying on the exemption from registration provided by Rule 506 of Regulation D under the Securities Act ("Rule 506") in connection with a securities offering structured as a private placement. As a consequence of the settlements, many of our funds are currently disqualified from raising capital using Rule 506 offerings. This could negatively affect our ability to raise capital for these funds, and our ability to offer and sell fund interests to certain investors in certain U.S. states may be impaired. The inability of many of our funds to raise capital in Rule 506 offerings may also result in additional expenses. The potential negative impact of the FCPA settlements on our ability to raise or retain capital for our funds could adversely affect our business, financial condition or results of operations. ${ }^{110}$

Scrutiny under the FCPA and related laws often cause business organizations to become excessively risk averse and back away from potential deals because of the potential implications of bribery laws. For instance, 
in the immediate aftermath of JPMorgan's scrutiny concerning its internship and hiring practices in China (namely the allegation that the company hired the children of influential alleged Chinese officials), the company withdrew from several lucrative financial deals. The Wall Street Journal reported that JPMorgan withdrew "from underwriting midtier lender China Everbright Bank Co.'s \$2 billion initial public offering in Hong Kong" because in the aftermath of the company's scrutiny "deals have faced intense scrutiny from the U.S. bank's compliance division."111 Likewise, it was reported that JPMorgan "pulled out of a \$1 billion initial public offering of a Chinese chemical company and won't seek a role in the IPO of a Chinese state-owned train maker, as the bank walks away from deals that could come under scrutiny from U.S. investigators probing its hiring practices in China." Investment bank IPO fees are typically $1.5-3 \%$ of the deal's size and JPMorgan's risk aversion, coupled with its pre-enforcement action professional fees and expenses, likely far exceeded the \$203 million the company ultimately paid in the actual enforcement action regarding its internship and hiring practices. ${ }^{112}$

FCPA and related scrutiny can also crimp company growth and make general business conditions more difficult. According to the Wall Street Journal, Wal-Mart's growth plans in India stalled and one of "biggest reasons [was] a compliance crackdown" at the company following its scrutiny. ${ }^{113}$ Among other things, the article noted that "developing and operating stores in India is complicated, even for locals" because "dozens of permits and licenses are required from various agencies down to the municipal level" and in response to its scrutiny Wal-Mart "enlisted a phalanx of lawyers from a U.S. firm to develop compliance procedures and train employees in India" and that "the company also has begun requiring its Indian landlords to attest that they haven't greased any government palms." In short, "running people through those hoops" slowed Wal-Mart's expansion plans in India.

Enforcement of the FCPA and related laws may also cause a company to exit a foreign country altogether. ${ }^{114}$ For instance, Ralph Lauren resolved an enforcement action based on alleged conduct in Argentina and thereafter "ceased retail operations" in the country. BioRad Laboratories resolved an enforcement actions based in part on alleged conduct in Vietnam and thereafter "closed its Vietnam office." Construction and drilling company Layne Christensen resolved an enforcement action based on alleged conduct in a variety of African countries and thereafter its Minerals Services division exited Africa. General Cable resolved an enforcement action based in part on alleged 
conduct in Thailand and during its scrutiny completed the sale of its Thai operations. To state the obvious, winding down operations in a foreign country and exiting the country altogether is not a timefree or cost-free exercise. In several of these examples, the DOJ/SEC seemingly viewed the country exits as a good thing and specifically mentioned them in the resolution documents as a "remedial measure." Yet from a policy standpoint, are such "country exits" in the aftermath of scrutiny or enforcement necessarily a good thing? Is a foreign country (including its government and citizens) in a better position when an otherwise ethically sound company (notwithstanding it resolving an enforcement action based on rather isolated conduct) leaves a country? Who takes that company's place and what if that company has less of a commitment to compliance and ethics?

\section{Management issues}

Scrutiny can also be distracting for company management forced to focus on FCPA issues instead of other core business issues. For instance, Wal-Mart disclosed that its scrutiny "may require the involvement of certain members of the Company's senior management that could impinge on the time they have available to devote to other matters relating to the business." 115 Another instructive example involved gas detection company RAE Systems which resolved a \$3 million enforcement action concerning alleged improper payments to Chinese officials made by employees of two joint ventures majority owned and controlled by RAE Systems. ${ }^{116}$ In a subsequent revealing interview, the CFO at the time of the investigation and enforcement action discussed how the company's scrutiny came to derail his other job duties and caused him to have a falling out with the company's CEO.

Executive compensation is another "ripple" of scrutiny and enforcement that may uniquely impact corporate management. For instance, security systems company Diebold Inc. disclosed:

While conducting due diligence in connection with a potential acquisition in Russia, Diebold identified certain transactions and payments by its subsidiary in Russia [...] that potentially implicate the FCPA, particularly the books and records provisions of the FCPA. While the company's current assessment indicates that the transactions and payments in question do not materially impact or alter the company's financial statements, the company continues to collect information and is conducting an internal review of its global FCPA compliance. ${ }^{17}$ 
Thereafter, Diebold's Compensation Committee reduced the cash bonus of the company's President and CEO, concluding that "given the CEO's ultimate responsibility for the oversight of the company, as a result of the impact to the company of the global FCPA investigation it was appropriate that [his] cash bonus be reduced."118

The negative business effects of scrutiny and enforcement have become so pronounced that FCPA and related risks are often included among the generic risks (such as loss of key personnel, global economic conditions, and currency fluctuations) companies disclose to investors as required in most SEC filings. The annual report of manufacturer Gardner Denver Inc. provides a representative example in that the company disclosed, among other risk factors:

The risk of non-compliance with U.S. and foreign laws and regulations applicable to our international operations could have a significant impact on our results of operations, financial condition or strategic objectives. Our global operations subject us to regulation by U.S. federal and state laws and multiple foreign laws, regulations and policies, which could result in conflicting legal requirements. These laws and regulations are complex, change frequently, have tended to become more stringent over time and increase our cost of doing business. These laws and regulations include [...] anti-corruption and bribery laws such as the FCPA ... and local laws prohibiting corrupt payments to government officials. We are subject to the risk that we, our employees, our affiliated entities, contractors, agents or their respective officers, directors, employees and agents may take actions determined to be in violation of any of these laws, particularly as we expand our operations geographically through organic growth and acquisitions. An actual or alleged violation could result in substantial fines, sanctions, civil or criminal penalties, debarment from government contracts, curtailment of operations in certain jurisdictions, competitive or reputational harm, litigation or regulatory action and other consequences that might adversely affect our results of operations, financial condition or strategic objectives. ${ }^{119}$

As the above examples demonstrate, FCPA and related scrutiny and enforcement often result in numerous "ripples" beyond an actual enforcement action. It is particularly important for compliance professionals to understand and appreciate these other "ripples" because their aggregate impact often exceeds even the "three buckets" of financial exposure previously discussed. Moreover, compliance professionals often find themselves asking corporate management for additional resources and success is most likely obtained by using the 
above concepts that resonate with corporate management. In short, the numerous other "ripples" of scrutiny and enforcement are perhaps the most important reason why a diverse group of professionals need skills to spot risk.

As if the numerous issues already discussed in this chapter were not enough, a final reason a diverse group of professionals need skills to spot risk is because failure to do so can also exposure a business organization, as well as corporate management, to FCPA-related civil litigation as well as "offensive" uses of the FCPA to achieve a business objective or to further advance a litigating position.

\section{FCPA-related civil litigation}

Although courts have held that the FCPA does not provide a private right of action (i.e. only the DOJ or SEC can bring actual FCPA enforcement actions), plaintiffs' lawyers representing shareholders often target directors and executive officers of companies subject to scrutiny or enforcement with civil suits representing yet another "ripple" of scrutiny and enforcement. Two types of shareholder lawsuits often follow scrutiny or enforcement: derivative claims alleging director and officer breach of fiduciary duty and securities fraud class action claims. These lawsuits often follow a predictable pattern in that in the days and weeks following a business organization resolving an enforcement action or merely being the subject of scrutiny plaintiffs' firms representing shareholders launch purported investigations and lawsuits often begin to rain down on the company, its board of directors, or executive officers.

For instance, a feeding frenzy soon followed SciClone Pharmaceuticals' previously highlighted stock price drop upon disclosing scrutiny. The same day, four separate plaintiffs' firms announced investigations of SciClone on behalf of shareholders to determine whether securities laws were violated. ${ }^{120}$ The next day, four additional plaintiff's firm announced similar investigations, the following days saw numerous other investigations, and within three days of the disclosure the first securities class action lawsuit was filed. A similar feeding frenzy also followed Wal-Mart's previously highlighted stock price drop after the New York Times front-page article regarding alleged conduct in Mexico. Within 48 hours, several plaintiffs' firms announced investigations on behalf of shareholders and within 10 days shareholder civil suits tracking the Times article began to pour in against the company 
and its directors and executive officers. ${ }^{121}$ Approximately one month after the Times article, Wal-Mart disclosed:

The Company is a defendant in several recently-filed lawsuits in which the complaints closely track the allegations set forth in a news story that appeared in the New York Times [. . .]. One of these is a securities lawsuit $[\ldots]$ in which the plaintiff alleges various violations of the $[\mathrm{FCPA}] \ldots$ and asserts violations of [the securities laws] relating to certain prior disclosures of the Company. [...] In addition, eleven derivative complaints were filed [...] also tracking the allegations of the Times story, and naming various current and former officers and directors as additional defendants. The plaintiffs in the derivative suits [...] allege, among other things, that the defendants who are or were directors or officers of the Company breached their fiduciary duties in connection with oversight of FCPA compliance. ${ }^{122}$

In terms of derivative actions, the following context is important. The internal affairs of a corporation, such as the responsibilities of corporate directors and the rights of shareholders, are governed by state law. State law, including most prominently Delaware law, provides directors with broad discretion to manage the corporation subject to their fiduciary duties to the corporation and its shareholders. A director's fiduciary duties include the duty of care and the duty of loyalty including its subsidiary component the duty of good faith. In a notable case in the corporate director context, a court observed:

The sentinel asleep at his post contributes nothing to the enterprise he is charged to protect [... ] Shareholders have a right to expect that directors will exercise reasonable supervision and control over the policies and practices of a corporation. The institutional integrity of a corporation depends upon the proper discharge by directors of those duties. ${ }^{123}$

A corporate director's duty of good faith has evolved over time to include an obligation to attempt in good faith to assure that an adequate corporate information and reporting system exists. In the notable Caremark decision by the influential Delaware Court of Chancery, the court held that a director's failure to do so, in certain circumstances, may give rise to individual director liability for breach of fiduciary duty. In Stone v. Ritter, the Delaware Supreme Court provided the following necessary conditions for director oversight liability under the so-called Caremark standard: (i) a director utterly failed to implement any reporting or information system or controls; or (ii) having implemented such systems or controls, a director failed to monitor or 
oversee the corporation's operations. ${ }^{124}$ The court held that both situations require a showing that a director knew that they were not discharging their fiduciary obligations and courts have widely recognized that a director's good faith exercise of oversight responsibility may not necessarily prevent employees from violating criminal laws or from causing the corporation to incur significant financial liability or both.

Derivative claims in the FCPA context are often based one or more of the following alleged actions or failures of directors and/or officers:

- participation in, concealment of, or failure to prevent the FCPA violations;

- preparation, review, and/or signing of false and misleading public statements;

- failure to comply with the company's code of business conduct or similar policy requiring FCPA compliance;

- failure to require the company to implement internal controls in compliance with the FCPA's antibribery provisions or books, records, and internal accounting provisions;

- failure to monitor the company's compliance with, or implement mechanisms for enforcement of, the company's anti-corruption policies and procedures;

- failure to implement information and reporting systems to ensure senior management and the board of directors have adequate information about the company's business and operations, material events, and compliance;

- failure to remedy any illegal conduct or direct the company to institute suit against current or former board members and officers for permitting FCPA violations;

- and failure to oversee, manage, and operate the company in a lawful and ethical manner. ${ }^{125}$

In terms of securities fraud actions, given how scrutiny and enforcement under the FCPA and related laws can impact a company's stock price, it is not surprising that such actions are another frequent form 
of shareholder litigation and the following context is important. The securities laws are based on the general premise that issuers make full and complete disclosure of all material facts relevant to its business. Although materiality is a murky concept, courts have construed this key concept to mean all information, whether positive or negative, that might be relevant to an investor's decision to buy, sell, or hold a security. The securities laws foundation of full and complete disclosure of all material facts is enforced through, among other provisions, Section 1o(b) of the Exchange Act and its associated Rule 1ob-5. Section 1o(b) generally prohibits the use of "any manipulative or deceptive device or contrivance in contravention of such rules and regulations as the SEC may prescribe as necessary or appropriate in the public interest or for the protection of investors." Rule $1 \mathrm{ob}-5$ supplements Section 10 (b) by making it unlawful for any person, directly or indirectly: (i) to employ any device, scheme or artifice to defraud; (ii) to make any untrue statement of a material fact or to omit to state a material fact necessary in order to make the statements not misleading; or (iii) to engage in any act, practice, or course of business which operates or would operate as a fraud or deceit upon any person - in connection with the purchase or sale of any security.

Securities fraud claims in the FCPA context generally allege that a company's public disclosures regarding potential FCPA violations and/or the potential settlement with the DOJ or the SEC were misleading in themselves or are proof of material misstatements in the company's prior public statements regarding one or more of the following topics:

- the nonexistence of FCPA violations and improper accounting of funds used in illegal activity;

- the quality of the company's internal controls;

- the company's general compliance with corporate policies, the FCPA, and other applicable laws;

- the risks and costs associated with an FCPA investigation, including legal and consulting fees and disruptions to the company's operations;

- predictions regarding the results, effects, or ultimate materiality of an FCPA-related investigation; 
- the company's profitability or financial performance following the cessation of illegal activity and/or any decision to suspend certain operations due to illegal conduct; and

- the financial impact of increased monitoring expenses. ${ }^{126}$

In such cases, plaintiffs' typically assert that because of the issuer's false statements or omissions: "(1) the market price of the company's securities was artificially inflated and maintained; and (2) shareholders suffered losses when the stock price fell following the issuance of corrective disclosures and the materialization of risks previously concealed by the defendants (i.e., then the 'truth' was revealed)."127

Given the substantive elements, as well as procedural pleading requirements, of derivative and securities fraud actions a high percentage of these actions in the FCPA context fail to survive the motion to dismiss stage of litigation. ${ }^{128}$ The few actions that do survive a motion to dismiss are typically settled and a trial on the merits rarely occurs because companies often make the business decision to settle for nuisance value and often backed by insurance coverage. A typical corporate position concerning settlement of FCPA-related civil litigation was articulated by the Chief Financial Officer of Maxwell Technologies, a company that resolved an approximate \$14 million FCPA enforcement action based on conduct in China. ${ }^{129}$ During an investor call, the CFO stated:

As we have disclosed in past public filings ..., two shareholders had alleged that certain of our past and current officers and directors failed to prevent us from violating the [FCPA]. [...] [M]ediation was held and a proposed settlement was reached wherein $\$ 3$ million would be paid to plaintiff's counsels, with $\$ 2.7$ million to be paid by our insurance carrier, and $\$ 290,000$ would be paid by the Company. [...] Without admitting any wrongdoing, the defendants to this suit are willing to enter into this settlement in order to expedite resolution of the matter, and to relieve the defendants and the Company from further financial burden. We are pleased that this suit is near final settlement, and look forward to putting this matter behind us. ${ }^{130}$

Even though FCPA-related civil suits rarely survive the motion to dismiss stage of litigation, according to an analysis "a number of FCPArelated securities fraud suits have settled for amounts in excess of the penalty assessed by the DOJ and/or SEC" in the underlying enforcement action. ${ }^{131}$ Most notably, in connection with its scrutiny under the FCPA and related laws Petrobras (a Brazilian oil and gas company with 
shares traded in the U.S.) agreed to pay $\$ 2.95$ billion to resolve various private securities fraud actions based on alleged false or misleading statements or omissions in its securities filings related to its business practices. Even so, pursuant to the settlement Petrobras expressly denied liability and stated that the settlement was "in the company's best interest and that of its shareholders, given the risks of a verdict advised by a jury, particularities of US procedure and securities laws, as well its assessment of the status of the class action and the nature of such litigation in the United States". ${ }^{132}$

Given the frequency in which shareholder litigation follows FCPA scrutiny or enforcement and given the largely unsuccessful track record of such cases surviving the motion to dismiss stage, the question should be asked - does the majority of shareholder litigation in the FCPA context serve a purpose or are such actions merely parasitic attempts to feed-off of scrutiny and enforcement? For instance, a Forbes columnist wrote under the title "Plaintiff Lawyers Join The Bribery Racket":

The Justice Department's unprecedented campaign to enforce a oncebackwater statute called the [FCPA] has made corporate lawyers and accountants rich as big companies pay big law and accounting firms to investigate and defend potential violations. Plaintiff lawyers have noticed the enormous fees, which are often reaching into the hundreds of millions of dollars, enhanced FCPA enforcement is generating and are moving to extract their own cut. [...] The unintended consequences of the Justice Department's FCPA policy simply continue to mount. [... . Now the plaintiff lawyers are trying to join the fun. [...] What is clear is that the cost of enhanced FCPA enforcement on U.S. corporations keeps going up. And that more lawyers are finding ways to get rich off of it. ${ }^{133}$

When scrutiny or enforcement is the result of board of director or executive officer conduct, or the condoning or encouraging of such conduct by those with fiduciary duties, such civil suits or investigations would seem to be warranted and in the public interest. While there have been a few enforcement actions involving executive conduct at the highest levels of the company, the vast majority of enforcement actions do not allege any knowledge, participation or acquiescence in the conduct at issue by the board of directors or executive officers. In this typical scenario, shareholder litigation would seem to be merely an attempt by plaintiffs' lawyers to feed off scrutiny and enforcement. As with others things in the FCPA's modern era, shareholder litigation seems to have spiraled out of control and an FCPA practitioner rightly observed: 
Setbacks in court do not appear to have slowed the pace of new cases filed against corporations and their directors after FCPA disclosures. As the DOJ and SEC bring more cases, and as more companies voluntarily disclose potential FCPA violations, the trend of related civil litigation is likely to continue. In attempting to satisfy the expectations of the DOJ and SEC, a company's thorough internal investigation may also serve as the roadmap for a civil litigant. Companies negotiating with the DOJ and SEC must therefore balance the government's requests for the results of internal investigations with the risk of waiver of privilege and subsequent production to civil litigants. As a result of these practical considerations, reputational risk, and expenses involved in litigation, companies targeted by civil suits will feel pressure to settle, potentially even before the DOJ or SEC takes action. ${ }^{134}$

Regardless of the substantive merits of much FCPA related shareholder litigation, the take-away point here is that such civil litigation following an enforcement action or mere scrutiny represents yet another "ripple" and one can that may uniquely impact corporate management.

\section{"Offensive" use of the FCPA}

Whether it's a DOJ or SEC enforcement action, a related foreign law enforcement action, or a related civil suit brought by plaintiffs' lawyers representing shareholders, business organizations are typically in a defensive posture when it comes to the FCPA. Even if a company is not involved in an enforcement action or related litigation, the FCPA still often impedes a business objective such as not acquiring a foreign target or not engaging a foreign agent because of risk. While such defensive positions continue to dominate, the FCPA is increasingly being used offensively to achieve a business objective or to advance a litigating position.

As to the former, Dish Network and Tokyo-based SoftBank were battling for control of wireless carrier Sprint Nextel. Among the regulatory approvals SoftBank needed to complete the transaction was Federal Communications Commission approval of a license transfer from Sprint Nextel to SoftBank. In opposing the transfer, Dish Network cited an FCPA enforcement action against UTStarcom in which the company agreed to pay \$3 million "for the actions of UTS-China [its wholly-owned subsidiary] and its employees and agents, who arranged and paid for employees of Chinese state-owned telecommunications companies to travel to popular tourist destinations in the United States, including Hawaii, Las Vegas and New York City." ${ }^{35}$ The link Dish Network made between the FCPA enforcement action and its 
battle with SoftBank for Sprint Nextel was that Softbank's founder Masayoshi Son was on the board of UTStarcom during certain time periods relevant to the conduct at issue in the enforcement action. ${ }^{136}$ Dish Network asserted that the UTStarcom enforcement action was "relevant to the public interest analysis of the proposed transaction." In reply, Softbank stated that the UTStarcom enforcement action was not relevant to its attempt to gain control of Sprint Nextel and asserted:

[The enforcement action did] not involve SoftBank or Mr. Masayoshi Son, Chairman and CEO of SoftBank. The settlement documents do not name, implicate, or otherwise relate to SoftBank or Mr. Son, and are legally and factually irrelevant to this proceeding.

DISH suggests that these settlements raise a potential issue in this proceeding because Mr. Son at one time served as the Chairman of the Board of UTSI. Neither the DOJ or SEC settlement documents, however, even mention SoftBank or Mr. Son. This is hardly surprising. Mr. Son was not an operating officer of UTStarcom at any time and the alleged violations came to light years after Mr. Son left the Board, which he did in 2004. ${ }^{137}$

Another example of offensive use of the FCPA in a battle for corporate control involved Central European Distribution Corporation (CEDC), a large vodka producer headquartered in the U.S. that disclosed:

There has been a breach of the books and records provisions of the [FCPA] and potentially other breaches of the FCPA. It was determined that payments or gifts were made in a foreign jurisdiction in which the Company operates, and that there was a failure to maintain documentation in respect of certain of these payments or gifts adequate to establish whether there was a valid business purpose in making the payments or gifts. Furthermore, our management also identified a material weakness in our internal control over financial reporting regarding the implementation of our policy on compliance with applicable laws [...]. Our conclusion that this deficiency is a material weakness in our internal control over financial reporting is not based on misstatements in our historical consolidated financial statements or our consolidated financial statements [. . ], but instead on the determination that we did not design or maintain sufficient policies, procedures, controls, communications or training to deter or prevent the risk of violations of law, including the [FCPA]. ${ }^{138}$

Shortly thereafter, Russian billionaire Roustam Tariko (the founder of CEDC rival Russian Standard and CEDC's largest shareholder) claimed that CEDC executives themselves were the subject of an FCPA 
investigation. The claims of CEDC's largest shareholder caused the company to issue a letter to shareholders that stated:

As you may be aware ... Mr. Roustam Tariko, Chairman of Russian Standard, published a letter to CEDC investors that has created anxiety and confusion in the marketplace. What you may not be aware of is that Mr. Tariko's letter was published less than 48 hours after the CEDC Board voted 5 to 3 (the 3 being Mr. Tariko and his Board designees) against Mr. Tariko's request that he be given total control over CEDC's operations and finance. This request follows repeated attempts by Russian Standard to remove the interim CEO. The purpose of this letter is to provide you with [among other things] correct information regarding FCPA matters. ${ }^{139}$

The letter then stated that "despite suggestions in the Russian Standard letter to the contrary, the company is NOT on notice that any of its current executives are under investigation with respect to FCPA violations or otherwise."

Perhaps the most high-profile instance of offensive use of the FCPA involved the boardroom battle between Wynn Resorts and its board member Kazuo Okada. Wynn Resorts disclosed:

Wynn Macau, a majority owned subsidiary of Wynn Resorts, Limited (the "Company"), made a commitment to the University of Macau Development Foundation in support of the new Asia-Pacific Academy of Economics and Management. This contribution consists of a \$25 million payment ... and a commitment for additional donations of $\$ 10$ million each year for [ten years]. The pledge was consistent with the Company's longstanding practice of providing philanthropic support for deserving institutions in the markets in which it operates. The pledge was made following an extensive analysis which concluded that the gift was made in accordance with all applicable laws. The pledge was considered by the Boards of Directors of both the Company and Wynn Macau and approved by 15 of the 16 directors who serve on those boards. The sole dissenting vote was Mr. Kazuo Okada whose stated objection was to the length of time over which the donation would occur, not its propriety. Also as previously disclosed, Mr. Okada commenced litigation [...] in Nevada seeking to compel the Company to produce information relating to the donation to the University of Macau, among other things. [...] Following Mr. Okada's lawsuit, the Company received a letter from the $[\mathrm{SEC}]$ requesting that, in connection with an informal inquiry by the SEC, the Company preserve information relating to the donation to the University of Macau, any donations by the Company 
to any other educational charitable institutions, including the University of Macau Development Foundation, and the Company's casino or concession gaming licenses or renewals in Macau. ${ }^{140}$

While Wynn's disclosure did not specifically mention the FCPA, given that the company's disclosure of the SEC inquiry appeared to link the donation to the "Company's casino or concession gaming licenses or renewals in Macau," the disclosure seemingly implicated the FCPA. Indeed, Okada alleged in his complaint that "Wynn Macau's gaming concession expires - the last year of Wynn's donation commitment" and that he objected to the donation because the Chinese government owned the land on which the University is located.

Shortly thereafter, Wynn accused Okada of separate and distinct conduct that could implicate the FCPA. In a press release, Wynn announced that its "Compliance Committee has concluded a year-long investigation after receiving an independent report detailing numerous apparent violations of the [FCPA] by Aruze USA, Inc., its parent company Universal Entertainment Corporation, and its principal shareholder, Kazuo Okada." ${ }^{141}$ In the release, Wynn noted that its Compliance Committee engaged a variety of experts, including Louis Freeh (the former Director of the FBI), who conducted "a thorough independent investigation" which "uncovered and documented more than three dozen instances over a three-year period in which Mr. Okada and his associates engaged in improper activities for their own benefit in apparent violation of U.S. anti-corruption laws and gross disregard for the Company's Code of Conduct." According to the release, "Mr. Okada and his associates and companies appear to have engaged in a longstanding practice of making payments and gifts to his two chief gaming regulators at the Philippines Amusement and Gaming Corporation, who directly oversee and regulated Mr. Okada's Provisional Licensing Agreement to operate in that country." The Wynn releases further stated:

The Board has requested that Mr. Okada resign as a Director of Wynn Resorts. [...] The Freeh Report is the culmination of a year-long investigation by the Compliance Committee based on increasing concerns the Board had relating to the activities of Mr. Okada and Aruze USA, Inc. in the Philippines and statements made by Mr. Okada to Wynn Resorts' Directors that gifts to regulators are permissible in Asia. Mr. Okada is the only Director of Wynn Resorts who has continued to refuse to sign the Company's Code of Conduct or participate in mandatory Foreign Corrupt Practices Act training for Directors. 
Wynn's FCPA allegations against Okada were used by the company to support its finding that Okada was an "unsuitable person" under Nevada gaming regulations and thus justified Okada's removal from Wynn's board. ${ }^{142}$ The boardroom battle occurred in the context of Wynn's attempt to purchase Okada's 20\% stake in the company at an approximate $30 \%$ discount. Okada ultimately resigned from Wynn's board and in doing so stated: "I no longer believe it is appropriate for me to serve on the Board of Directors of a company that is behaving in a manner that I deeply believe to be unethical."143

In addition to the FCPA being used offensively to achieve a business objective, with increasing frequency the FCPA is also being used offensively to advance a litigating position. As previously indicated, while certain courts have held that the FCPA does not contain a private right of action, plaintiffs nevertheless may attempt to use bribery-related conduct that could implicate the FCPA and related laws in bringing a cause of action under the Racketeer Influenced and Corrupt Organizations Act (RICO). To establish a violation of any of the substantive offenses under RICO, a plaintiff must show that a defendant engaged in a "pattern of racketeering," which requires at least two acts of racketeering activity and a violation of the Travel Act is one of the enumerated predicate offenses under RICO. The Travel Act, enacted prior to the FCPA, is part of the racketeering chapter of the criminal code and prohibits interstate and foreign travel or transportation in aid of racketeering enterprises. Specifically, the Travel Act prohibits travel in interstate or foreign commerce or use of the mail or any facility in interstate or foreign commerce with intent to, among other things, carry on "any unlawful activity," which is defined to include bribery in violation of state law. In short, conduct in violation of the FCPA is often in violation of state law, which in turn implicates the Travel Act, which in turn can implicate RICO given that a Travel Act violation is a predicate offense under RICO.

For instance, Aluminum Bahrain BSC ("Alba") (one of the largest aluminum smelters in the world and owned by, among others, the government of Bahrain) filed a civil lawsuit against Alcoa Inc. (the world's leading producer of primary aluminum products) alleging RICO violations. The complaint alleged that certain Aloca entities and their agents engaged in a conspiracy over a 15 -year period to defraud Alba and specifically alleged that the defendants: (i) illegally bribed officials of the government of Bahrain and (or) officers of Alba in order to force Alba to purchase alumina at excessively high prices; (ii) illegally bribed 
officials of the government of Bahrain and (or) officers of Alba and issued threats in order to pressure Alba to enter into an agreement by which Alcoa would purchase an equity interest in Alba; and (iii) assigned portions of existing supply contracts between Alcoa and Alba for the sole purpose of facilitating alleged bribes and unlawful commissions. ${ }^{144}$ After the judge denied the defendants' motion to dismiss, Aloca agreed to settle the case by paying Alba approximately $\$ 85$ million and the action represented the "first time that a foreign-owned corporation has successfully sued a U.S. company in a federal court to recover losses suffered due to allegations of corrupt activity." 145

As the following cases demonstrate, FCPA-related civil litigation often involves other causes of action as well.

- After Innospec resolved an FCPA enforcement action, NewMarket Corp. (a competitor company) learned of Innospec's conduct from the DOJ and SEC resolution documents including the allegation that Innospec's bribe payments in Iraq ensured that a field test of a competitor's product failed. Based on Innospec's acknowledgment of this conduct in resolving the enforcement action, the competitor filed a civil case against Innospec alleging violations of the Robinson-Patman Act, the Virginia Antitrust Act, and the Virginia Business Conspiracy Act. Innospec agreed to resolve the case by agreeing to pay NewMarket approximately $\$ 45$ million. ${ }^{146}$

- In the aftermath of various FCPA enforcement actions alleging bribery and corruption at Venezuela's national oil company Petroleos de Venezuela, S.A. (PDVSA), Harvest Natural Resources Inc. alleged that various former high-ranking PDVSA officials and others "conspired to force American companies to pay-to-play in Venezuela's oil and gas industry." In filing a lawsuit asserting violations of RICO, the Sherman Act, the Robinson Patman Act, and the Texas Free Enterprise and Antitrust Act, Harvest alleged: "because Harvest and its business partners refused four separate \$10 million bribe demands solicited by the Defendants, Venezuela's Ministerio del Poder Popular de Petroleo y Mineria withheld final approval for Harvest to sell its Venezuelan energy assets to two different buyers ... (first for $\$ 725$ million and then for $\$ 400$ million). As a result, Harvest was forced to sell the same assets for approximately $\$ 255$ million, at a loss of $\$ 470$ million, and unexpectedly to cease doing business and wind up its affairs." 147 
- After medical products company Misonix disclosed FCPA scrutiny related to "the business practices of [an] independent Chinese entity that previously distributed its products in China," the former Chinese distributor filed a lawsuit against Misonix and certain officers and directors alleging that the company improperly terminated its contract. The civil complaint sought "various remedies, including compensatory and punitive damages, specific performance and preliminary and post judgment injunctive relief, asserts various causes of action, including breach of contract, unfair competition, tortious interference with contract, fraudulent inducement, and conversion." 148

One of the most interesting "offensive" uses of the FCPA concerned civil litigation between Louis Berger International and Richard Hirsch (a former executive of the company who at times oversaw operations in Indonesia and Vietnam). After Louis Berger resolved a \$17 million FCPA enforcement (based on the conduct of Hirsch and another employee) in connection with projects in Indonesia, Vietnam, India and Kuwait, it sued Hirsch for breach of fiduciary duty and the parties settled for undisclosed terms. ${ }^{149}$

"Offensive" use of the FCPA to advance a litigating position is not just limited to business organizations as individuals are also increasingly citing the FCPA to support claims of breach of contract or wrongful termination of employment as demonstrated by the below examples.

- Khaled Asadi (a former employee of a wholly-owned subsidiary of General Electric Company (G.E.)), filed a civil complaint alleging that G.E. harassed and pressured him to vacate his position, and ultimately terminated him after he informed his supervisor and G.E.'s Ombudsperson "regarding potential violations of the FCPA committed by G.E. during negotiations for a lucrative, multi-year deal with the Iraqi Ministry of Electricity." ${ }^{150}$

- Stephen Lowe (a former Allison Transmission Managing Director for operations in China, Japan, and Korea) filed a civil complaint against the company alleging that Allison fired him because he "refused to engage in violations of the FCPA."151 Among other things, Lowe alleged that: (i) he witnessed Allison's Commercial Director of Asia Strategy deliver a cash-filled envelope to Beijing City Bus officials during dinner; (ii) he heard the Commercial 
Director describe how he purchased silver jewelry for Chinese government officials "in order to please the officials"; (iii) the Commercial Director bragged about winning a Beijing City Bus Olympics contract by doing "whatever it took to please the officials" "including giving gifts, money and prostitutes"; and (iv) the Commercial Director "deliberately lost" high-stakes card games to "key Beijing City Bus officials." According to Lowe's complaint, Allison's Vice President of International Sales and Marketing knew and approved of certain of the Commercial Director's conduct and Lowe further alleged that "a month before Allison fired him" he disclosed his concerns about the Commercial Director and the Vice President to Allison's Marketing Manager.

Such "noisy exits" by employees alleging wrongful termination of employment can also be the origins of high-profile corporate FCPA scrutiny. For instance, casino company Las Vegas Sands's scrutiny began when Steven Jacobs (the former President of the company's Macau operations) filed a civil complaint against the company alleging breach of contract and tort-based causes of action. ${ }^{152}$ Jacobs alleged, among other things, that the company's "notoriously bellicose" CEO and majority shareholder made several "outrageous demands" upon him including "demands that Sands China continue to use the legal services of a Macau attorney [...] despite concerns that [the individual's] retention posed serious risks" under the FCPA. The conduct alleged in the civil lawsuit ultimately resulted in parallel DOJ and SEC enforcement action against Las Vegas Sands that the company resolved for approximately $\$ 16$ million..$^{153}$

Wrongful termination claims brought by individuals can also follow FCPA scrutiny and enforcement. A high-profile example concerned civil litigation initiated by Sanford Wadler (the former General Counsel and Secretary of Bio-Lab Laboratories) against the company in the aftermath of Bio-Rad resolving a \$55 million FCPA enforcement action based on alleged conduct in Russia, Thailand and Vietnam. Wadler's civil complaint alleged that Bio-Rad and certain executive officers and board members engaged in various unfair employment practices including terminating him for blowing the whistle on certain potential FCPA issues. Wadler's claims were fully litigated and a jury awarded him $\$ 2.9$ million in back pay and stock compensation and $\$ 5$ million for punitive damages and the trial court doubled the compensatory award pursuant to applicable law for a total award of approximately \$11 million. ${ }^{154}$ 
The take-away point from this section on the "ripple effects" of scrutiny and enforcement is that a business organization will experience wide-ranging financial consequences from FCPA and related scrutiny and enforcement beyond an actual government enforcement action. These "ripples" - ranging from pre- and post-enforcement action professional fees and expenses, various negative business effects, and FCPA-related civil litigation as well as various "offensive" uses of the FCPA - should make clear that compliance is not just a legal issue, but a general business issue that needs to be on the radar screen of various professionals who can assist in risk management and who should view the importance of compliance holistically and not merely through the narrow lens of actual enforcement actions.

More broadly, this chapter has highlighted why a diverse group of professionals need skills to spot risk and debunked the narrative that complying with the FCPA and related laws is easy given that the overwhelming majority of business organizations do business in the global marketplace with a commitment to compliance, yet subject to unrealistic legal standards and/or difficult and complex business conditions that often serve as the root cause of scrutiny and enforcement. With a clear understanding of why skills to spot risk are important, the next chapter begins to construct your "FCPA goggles" by analyzing the core elements of the FCPA's anti-bribery provisions as well as related risk management strategies.

\section{NOTES}

1 MarketWatch, "S\&P 500 Companies Generate Barely Over Half Their Revenue at Home," (Aug. 19, 2015).

2 Jonathan Rockoff, “Abbott Looks to India for Shot in Arm”, Wall Street Journal (Aug. 26, 2010).

3 SEC Release, "SEC Charges Smith \& Wesson with FCPA Violations," (July 28, 2014).

4 Charles Denny \& David Weissbrodt, "Business Forum: Good Companies Don't Bribe. Period”, Minneapolis StarTribune (May 29, 2012).

5 Nick Wingfield, New York Times, “U.S. Said to Look Into Microsoft Bribery Allegations” (Mar. 19, 2013).

6 Microsoft Blog, “Our Commitment to Compliance” (Mar. 19, 2013).

7 Press Release, U.S. Department of Justice, “Transcript of Press Conference Announcing Siemens AG and Three Subsidiaries Plead Guilty to Foreign Corrupt Practices Act Violations" (Dec. 15, 2008).

8 FCPA Professor, "Where Was The BizJet Board?," (Apr. 11, 2013).

9 FCPA Professor, "Former DOJ FCPA Chief Supports FCPA Compliance Defense," (Oct. 4, 2011).

10 FCPA Professor, "Friday Roundup," (Mar. 8, 2013).

11 FCPA Professor, "Friday Roundup," (Feb. 28, 2014).

12 FCPA Professor, "Companies That Have Resolved FCPA Enforcement Actions Or Are Currently Under FCPA Scrutiny Are Helping To Change The World," (Sept. 7, 2016). 
13 U.S. Attorneys' Manual, 9-47.00o - Foreign Corrupt Practices Act Of 1977.

14 FCPA Professor, “SEC Official - "FCPA Law .. Is Not Well Developed,” (Dec. 5, 2013).

15 A Resource Guide to the U.S. Foreign Corrupt Practices Act.

16 FCPA Professor, “The Guidance Press Conference," (Nov. 15, 2012).

17 Id.

18 Id.

19 Id.

20 FCPA Professor, "Do Lanny Breuer And Robert Khuzami Actually Read FCPA Enforcement Actions?" (Dec. 13, 2012), containing links to original source documents.

21 FCPA Professor, "Andrew Weissmann On The FCPA - It Is "Very Easy For The People At The DOJ And SEC To Basically Impose A Tax For Doing Business” In Certain Countries," (Sept. 2o, 2016).

22 Jones Day Commentary, "U.S. Department of Justice and Securities and Exchange Commission Guidance on the Foreign Corrupt Practices Act: What to Expect" (Sept. 2012).

23 Corruption, Crime \& Compliance, "It Takes a Village ... To Commit Bribery," (Oct. 29, 2017).

24 DOJ Principles of Federal Prosecution of Business Organizations, 9-28.80o, Corporate Compliance Programs.

25 Press Release, U.S. Department of Justice, "Assistant Attorney General Lanny A. Breuer of the Criminal Division Speaks at the Annual Meeting of the Washington Metropolitan Area Corporate Counsel Association" (Jan. 26, 2011); Lanny A. Breuer, Assistant Attorney General, Criminal Division U.S. Department of Justice, Prepared Remarks to Compliance Week 2010 5 th Annual Conference for Corporate Financial, Legal, Risk, Audit \& Compliance Officers (May 26, 2010).

26 The Metropolitan Corporate Counsel, "Former Chief Of DOJ Fraud Unit Discusses Healthcare And FCPA Enforcement” (Sept. 29, 2012).

27 FCPA Professor, “2016 FCPA Enforcement Begins With SEC Action Against SAP," (Feb. 2, 2016).

28 In the Matter of Nordion (Canada) Inc., Release No. 77290 (Mar. 3, 2016).

29 FCPA Professor, "Q \& A With Martin Weinstein" (May 18, 2010).

30 Philip Urofsky, "The Ralph Lauren FCPA Case: Are There Any Limits to Parent Corporation Liability?" Bloomberg BNA Securities Regulation \& Law Report (May 6, 2013).

31 FCPA Professor, “The SEC's Recent Alter Ego Theories," (Feb. 29, 2016).

32 South China Morning Post, "Fire Officials Put the Nation at Risk as They Rake in Bribes" (June 9, 2013).

33 Peter Van Dyk, "From Iowa To Russia, Tractors Build Economic Bridge" National Public Radio (May 15, 2012).

34 FCPA Professor, "A Positive Correlation Between Bureaucracy And Corruption," (Jan. 12, 2018).

35 Letter from Steven A. Tyrell, Chief, Fraud Section, U.S. Department of Justice (Criminal Division), to Kimberly A. Parker, Attorney for Helmerich \& Payne, Inc. (July 29, 2009).

36 Complaint, SEC v. Delta \& Pine Land Co., No. 1:07-cv-01352 (D.D.C. July 25, 2007).

37 Information, U.S. v. Tyson Foods, Inc., No. 1:11-cr-0oo37-RWR (D.D.C. Feb. 10, 2011).

38 Foley \& Lardner and Panag \& Babu, "Anti-Bribery and Foreign Corrupt Practices Act Compliance Guide for U.S. Companies Doing Business in India”.

39 Transparency International, Global Corruption Barometer 2010; Kaushik Basu, "Why, for a Class of Bribes, the Act of Giving a Bribe Should Be Treated as Legal" (Mar. 2011).

40 FCPA Professor, "The First FCPA Enforcement Action Of 2017 Is A \$13 Million Joke," (Jan. 9, 2017).

41 FCPA Professor, "On National Drink Beer Day, AB InBev Agrees To Pay \$6 Million To Resolve FCPA (And Related) Enforcement Action,” (Sept. 29, 2016).

42 Diageo plc, Exchange Act Release No. 64978 (July 27, 2011). 
43 Complaint, SEC v. Westinghouse Air Brake Techs. Corp., No. o8-cv-706 (E.D. Pa. Feb. 14, 2008).

44 Information, U.S. v. Baker Hughes, Inc., No. 4:07-cr-00130 (S.D. Tex. Apr. 11, 2007).

45 Nigeria Country Profile, Business Anti-Corruption Portal.

46 Press Release, U.S. Department of Justice, "Oil Services Companies and a Freight Forwarding Company Agree to Resolve Foreign Bribery Investigations and to Pay More than $\$ 156$ Million in Criminal Penalties" (Nov. 4, 2010).

47 FCPA Professor, “Avon Resolves Long-Standing FCPA Scrutiny By Agreeing To \$135 Million Settlement," (Dec. 19, 2014); A Blemish - Nu Skin Enterprises Resolves SEC FCPA Enforcement Action Based On Its Chinese Subsidiary's “Charitable Donation,” (Sept. 21, 2016).

$48 \mathrm{Nu}$ Skin Enterprises Inc. Form 10-K filed February 16, 2018.

49 FCPA Professor, “Two For Tuesday In FCPA Enforcement Land - Akamai Technologies,” (June 8, 2016).

50 FCPA Professor, "Next Up - Telia As DOJ And SEC Announce Contemplated \$483 Million Net FCPA Enforcement Action," (Sept. 21, 2017).

51 FCPA Professor, "Issues To Consider From The Hitachi Enforcement Action," (Oct. 1, 2015).

52 FCPA Professor, "When A Government Customer Does Not Pay," (Feb. 15, 2018).

53 Id.

54 Avon 2009 annual report (filed March 2010).

55 FCPA Professor, "Checking In On Wal-Mart's Pre-Enforcement Action Professional Fees And Compliance Enhancements," (Feb. 21, 2018).

56 Nathan Vardi, “The Bribery Racket”, Forbes (June 7, 2010).

57 Memorandum in Support of the Proposed Plea Agreements and Deferred Prosecution Agreement, U.S. v. Alcatel-Lucent France S.A., et al, Case No. 10-cr-20906 (S.D. Fl. May 23, 2011).

58 Id.

59 Forbes, “The Bribery Racket," (June 7, 2010).

6o Wall Street Journal, "FCPA Inc.: The Business of Bribery," (Oct. 2, 2012).

61 Reuters, "Lawyers Need to Brake Their Bribe-Case Gravy Train," (Aug. 27, 2013).

62 FCPA Professor, "Friday Roundup," (Sept. 20, 2013).

63 DOJ Release, "Assistant Attorney General Leslie R. Caldwell Delivers Remarks at New York University Law School's Program on Corporate Compliance and Enforcement" (Apr. 17, 2015)

64 FCPA Professor, "Issues To Consider From The Avon Enforcement Action," (Dec. 22, 2014).

65 Law360 "Mixed Messages On Internal FCPA Probes Exasperate Attys" (Apr. 27, 2015).

66 Joel Schectman, “DOJ Wants Faster Anti-Bribery Investigations, Too," Wall Street Journal Risk E Compliance Journal (May 19, 2015).

67 For instance, the composition of FCPA settlement amounts in many corporate enforcement actions is controversial. Many FCPA enforcement actions involving both a DOJ and SEC component include features of "double-dipping" (in which the company pays an amount representing the benefit received from the alleged improper payments twice - first to the DOJ and then to the SEC). See FCPA Professor, "Double-Dipping," (June 4, 2013). Likewise, it is common in FCPA enforcement actions for the SEC to seek a disgorgement amount even in the absence of anti-bribery violations (a practice known as no-charged bribery disgorgement). See FCPA Professor, "No-Charged Bribery Disgorgement," (Aug. 22, 2011).

68 SEC Release, "SEC Charges Siemens AG for Engaging in Worldwide Bribery," (Dec. 15, 2008).

69 FCPA Professor, "Next Up - Telia As DOJ And SEC Announce Contemplated \$483 Million Net FCPA Enforcement Action," (Sept. 21, 2017).

70 FCPA Professor, "VimpelCom's Uzbekistan Bribery Scheme Nets \$397.5 Million FCPA Enforcement Action," (Feb. 19, 2016).

71 The Times of Israel, “Teva to Pay NIS 75 Million to Israel Authorities to Settle Foreign Bribe Claims," (Jan. 15, 2018). 
72 FCPA Professor, "Friday Roundup," (Apr. 26, 2013).

73 FCPA Professor, "More On Alliance One and Universal," (Aug. 25, 2010), containing links to original source documents.

74. FCPA Professor, "Friday Roundup," (Aug. 20, 2010).

75 FCPA Professor, "FCPA Settlement Amounts Have Come A Long Way In A Short Amount Of Time," (Dec. 3, 2013).

76 Gibson Dunn, “2013 Year End FCPA Update," (Jan. 6, 2014).

77 See for instance the Deferred Prosecution Agreement, U.S. v. Parker Drilling Co., Case 1:13-cr00176 (E.D. Va., Apr. 16, 2013).

78 Deferred Prosecution Agreement, U.S. v. Johnson \& Johnson, Case 1:11-cr-ooog9-JDB (D.D.C., Apr. 8, 2011).

79 Joseph Warin et al., “Somebody's Watching Me: FCPA Monitorships and How They Can Work Better," 13 University of Pennsylvania Journal of Business Law 321 (2011).

80 FCPA Professor, "The Work Of A Monitor And Checking In On Siemens" (Jan. 22, 2013), containing links to original source documents.

81 FCPA Professor, "Friday Roundup" (Apr. 13, 2012), containing links to original source documents.

82 FCPA Professor, “Faro's Monitor - Late and Expensive," (Dec. 27, 2010).

83 FCPA Professor, "The Gray Cloud Of FCPA Scrutiny Lasted Too Long In 2017," (Jan. 4, 2018).

84 FCPA Blog, “The FCPA's Long Shadow,” (Aug. 6, 2012).

85 SciClone Pharmaceuticals Inc., Form 10-K (filed Aug. 9, 2010).

86 Cognizant Technology Solutions Corporation, Form 8-K (filed Sept. 30, 2016).

87 FCPA Professor, "Unable To File Its Annual Report Due In Large Part To An FCPA Investigation, World Acceptance Corp. Stock Drops 12.4\%," (June 16, 2017).

88 Ohio National Fund Inc., Form N-CSR (Sept. 8, 2017).

89 Wall Street Pit, "NCR Corp (NCR): Downgraded as Potential FCPA Issues Add Meaningful Risk - Wedbush" (Aug. 14, 2012).

90 Moody's Investor Service, "Heightened Anti-Bribery and Corruption Enforcement Around FCPA to Continue," (May 2, 2016).

91 Fitch Ratings, "U.S. Foreign Corrupt Practices Act - No Minor Matter” (2010).

92 Reuters, "S\&P cuts Avon Products Inc" (Mar. 16, 2012).

93 Press Release, "Lockheed Martin Announces Agreement to Acquire Titan Corporation" (Sept. 15, 2003).

94 Press Release, “Lockheed Martin Updates Status of Review of Titan's International Consultants" (Mar. 5, 2004).

95 Press Release, "Lockheed Martin Terminates Merger Agreement with the Titan Corporation" (June 26, 2004).

96 Los Angeles Times, "Lockheed Drops Titan Merger After Delays by Bribery Probe" (June 26, 2004).

97 Press Release, U.S. Department of Justice (Mar. 1, 2005).

98 FCPA Professor, "FCPA And Then Some As Alere Resolves SEC Enforcement Action," (Sept. 29, 2017).

99 FCPA Professor, "Friday Roundup," (May 6, 2016).

100 FCPA Professor, "FCPA And Then Some As Alere Resolves SEC Enforcement Action," (Sept. 29, 2017).

101 FCPA Professor, “The FCPA's Long Tentacles,” (Aug. 3, 2010), containing links to original source documents.

102 Id.

103 Id.

104 FCPA Professor, “ABM Industries Discloses Merger Related Issue” (Dec. 26, 2011), containing links to original source documents. 
105 ABM Industries, Inc., Form 10-K (filed Dec. 20, 2012).

106 FCPA Professor, "FCPA Issues Can Reduce The Value Of A Merger" (June 14, 2012), containing links to original source documents.

107 FCPA Professor, "It's Not Easy Being Under Investigation for Two Years ..." (Mar. 15, 2010).

108 Press Release, U.S. Department of Justice, "Oil Services Companies and a Freight Forwarding Company Agree to Resolve Foreign Bribery Investigations and to Pay More Than \$156 Million in Criminal Penalties" (Nov. 4, 2010).

109 Bloomberg, "Och-Ziff Saw \$2.5 Billion of Outflows After Bribery Accord," (Nov. 2, 2016); FCPA Professor, "In Depth Into The Och-Ziff FCPA Enforcement Action," (Oct. 2, 2016).

110 Och-Ziff Capital Management Group LLC, Form 10-K (filed Feb. 23, 2018).

111 Prudence Ho \& Yvonne Lee, “J.P. Morgan Exits China IPO,” Wall Street Journal (Nov. 19, 2013).

112 FCPA Professor, "In Depth Into The JP Morgan FCPA Enforcement Action," (Nov. 18, 2016).

113 Megha Bahree, "Wal-Mart's Path to Power in India Hits Its Limits: The Lawyers" (Apr. 1, 2013).

114 FCPA Professor, "Merely A Coincidence Or FCPA-Related?," (Oct. 19, 2015).

115 FCPA Professor, "Scrutiny Alerts And Updates," (Apr. 3, 2013).

116 FCPA Professor, "The Former CFO Of RAE Systems Speaks,” (Aug. 14, 2012), containing links to original source documents.

117 FCPA Professor, "Friday Roundup," (July 30, 2010).

118 FCPA Professor, "Business Effects," (Mar. 21, 2012).

119 GardnerDenver Inc., Form 10-K (filed Feb. 27, 2013).

120 FCPA Professor, "SciClone - An FCPA Feeding Frenzy" (Oct. 13, 2010).

121 FCPA Professor, "Friday Roundup," (May 4, 2012).

122 FCPA Professor, "Friday Roundup," (June 8, 2012).

123432 A.2d 814 (1981).

124. 911 A.2d 362 (2006).

125 Jeffrey Johnston and Erika Tristan, "The Next FCPA Battleground: Private Civil Lawsuits Following Foreign Corrupt Practices Act Settlements With U.S. Government Authorities," Vinson E Elkins Securities Litigation Insights (Fall 2010).

126 Jeffrey Johnston and Erika Tristan, Vinson \& Elkins Securities Litigation Insights, "The Next FCPA Battleground: Private Civil Lawsuits Following Foreign Corrupt Practices Act Settlements With U.S. Government Authorities," (Fall 2010).

127 Id.

128 See e.g., FCPA Professor, "Development From The "Other Universe” - In Dismissing FCPARelated Civil Claims, Judge Rejects The Notion That The FCPA "Establishes A Statutory Floor For Adequate Internal Controls," (June 22, 2017).

129 Press Release, U.S. Department of Justice, "Maxwell Technologies Inc. Resolves Foreign Corrupt Practices Act Investigation and Agrees to Pay \$8 Million Criminal Penalty” (Jan. 31, 2011).

130 FCPA Professor, "Friday Roundup," (Mar. 2, 2012).

131 Amy Westbrook, "Double Trouble: Collateral Shareholder Litigation Following Foreign Corrupt Practices Act Investigations," 73 Ohio State Law Journal 1217 (2012).

132 Release, "Petrobras Signs Agreement in Principle to Settle Class Action in the U.S.," (Jan. 3, 2018).

133 Nathan Vardi, Forbes, "Plaintiff Lawyers Join The Bribery Racket” (Aug. 6, 2012).

134 James Tillen and Lauren Torbett, "Multiplying the Risks: Parallel Civil Litigation in FCPA Investigations," Bloomberg Law Reports - White Collar Crime (2010).

135 Press Release, U.S. Department of Justice, “UTStarcom Inc. Agrees to Pay \$1.5 Million Penalty for Acts of Foreign Bribery in China" (Dec. 31, 2009).

136 FCPA Professor, "Offensive Use of the FCPA," (June 6, 2013).

137 Id. 
138 FCPA Professor, "Friday Roundup," (Nov. 30, 2012), containing links to original source documents.

139 Id.

140 FCPA Professor, "Wynn Resorts \$135 Million University of Macau Donation The Subject Of SEC Scrutiny," (Feb. 14, 2012).

141 FCPA Professor, "Wynn's Boardroom Battle Royale," (Feb. 20, 2012), containing links to original source documents.

142 Chris Sieroty, "Okada Claims Against Wynn Resorts Ruled Baseless," Las Vegas Review-Journal (Feb. 4, 2013).

143 Chris Sieroty, Las Vegas Review-Journal, "Kazuo Okada Resigns From Wynn Resorts Board of Directors" (Feb. 23, 2013).

144 FCPA Professor, “Alcoa Agent Charged in the U.K." (Oct. 25, 2012), containing links to original source documents.

145 Akin Gump Press Release, “Akin Gump Secures Settlement Valued at \$447 Million in First-Ever RICO Claim by Foreign Company," (Oct. 9, 2012).

146 FCPA Professor, "Innospec Related News" (Aug. 10, 2010).

147 Complaint, Harvest Natural Resources, Inc. v. Juan Jose Mendoza Garcia, et al. (S.D. Tex. Feb. 16, 2018).

148 FCPA Professor, "Scrutiny Alerts and Updates," (May 8, 2017).

149 FCPA Professor, "Louis Berger Sues Former Executive For Exposing It To FCPA Liability," (June 21, 2016).

150 Christopher Matthews, "Former GE Exec Claims He Was Fired For Relaying FCPA Concerns," Wall Street Journal Corruption Currents (Feb. 7, 2012).

151 FCPA Professor, "Still Yet Another Noisy Exit," (Dec. 23, 2010).

152 FCPA Professor, "Another Noisy Exit," (Nov. 2, 2010).

153 FCPA Professor, "In An Unusual Development, The DOJ Brings A \$7 Million FCPA Enforcement Action Against Las Vegas Sands Nine Months After The SEC's \$9 Million Enforcement Action Based On The Same Conduct," (Jan. 20, 2017).

154 FCPA Professor, "Bio-Rad Appeals Approximate \$11 Million FCPA-Related Civil Verdict In Favor Of Its Former General Counsel," (Oct. 19, 2017). 